\title{
ABenomics: Preliminary AnAlysis And OUTLOOK
}

\author{
Joshua K. Hausman \\ University of Michigan
}

\author{
Johannes F. Wieland* \\ University of California, San Diego
}

April 2014

\begin{abstract}
In early 2013, Japan enacted a monetary regime change. The Bank of Japan set a two percent inflation target and specified concrete actions to achieve this goal by 2015 . Shinzo Abe's government is supporting this change with fiscal policy and structural reforms. We show that Abenomics ended deflation in 2013 and raised long-run inflation expectations. Our estimates suggest that Abenomics also raised 2013 output growth by 0.9 to 1.8 percentage points. Monetary policy alone accounted for up to a percentage point of growth, largely through positive effects on consumption. In the medium and long-run, Abenomics will likely continue to be stimulative. But the size of this effect, while highly uncertain, thus far appears likely to fall short of Japan's large output gap. In part this is because the Bank of Japan's two percent inflation target is not yet fully credible. We conclude by outlining how to interpret future data releases in light of our results.
\end{abstract}

${ }^{*}$ Hausman: Ford School of Public Policy and Department of Economics, University of Michigan. 735 S. State St. \#3309, Ann Arbor, MI 48109. Email: hausmanj@umich.edu. Phone: (734) 763-3479. Wieland: University of California, San Diego, Department of Economics, 9500 Gilman Dr. \#0508 La Jolla, CA 92093-0508. Email: jfwieland@ucsd.edu. Phone: (510) 388-2785. We are grateful for extensive comments from the editors, David Romer and Justin Wolfers, our discussants, Ben Bernanke and Paul Krugman, and participants in the spring 2014 Brookings Panel on Economic Activity meeting. We have also benefitted from conversations and assistance from Steven Braun, Gabriel Chodorow-Reich, Catherine Hausman, David Hausman, Koichiro Ito, Stefan Nagel, and Mu-Jeung Yang, as well as from comments from seminar participants at UCSD. We thank Walid Badawi, Matthew Haarer and Ben Meiselman for superb research assistance, and the International Policy Center at the Ford School of Public Policy for financial support. 


\section{Introduction}

A great monetary experiment is taking place in Japan today. In early 2013, the Bank of Japan announced a monetary policy regime change. Along with this monetary expansion, the government is enacting complementary fiscal policy and structural reforms. The hope is to end two decades of stagnation and deflation. In this paper, we provide a preliminary evaluation of these policies. We argue that Abenomics ended deflation in 2013 and raised output growth by 0.9 to 1.8 percentage points. Going forward, Abenomics will continue to have benefits, but so far appears unlikely to close Japan's large output gap. In part this is because the monetary regime change is not (yet) fully credible.

That Japan needs some new policies is clear. The Japanese economy has stagnated since 1992. Between 1993 and 2012, real GDP growth averaged just 0.8 percent. ${ }^{1}$ Prices have fallen most years since 1998. Economists have blamed Japanese policymakers for an insufficiently aggressive response to these trends. ${ }^{2}$ No longer. Shinzo Abe became prime minister on December $26^{t h}$, 2012. A member of the Liberal Democratic Party, Abe campaigned on a platform of radical action to end economic stagnation. His economic program (dubbed 'Abenomics') consists of monetary expansion, fiscal stimulus, and structural reforms. In a reference to a Japanese legend, these components are referred to as three arrows (Eichengreen, 2013).

The first arrow is a monetary policy regime change. Beginning in November 2012, thencandidate Abe argued that the Bank of Japan should increase its inflation target and engage in "unlimited easing." After his election on December $16^{\text {th }}$, Abe threatened to revise the law granting the Bank of Japan independence if it did not agree to a higher inflation target. ${ }^{3}$ The Bank of Japan acceded to Abe's demand, announcing a two percent inflation target at its meeting on January $22^{\text {nd }}$, 2013. While hardly extreme, two percent inflation would be the highest year-on-year inflation rate in Japan since 1991. In what we show was a more significant announcement, on April $4^{\text {th }}$ the new Bank of Japan governor, Haruhiko Kuroda, promised

\footnotetext{
${ }^{1}$ The data appendix describes our sources for series cited throughout the text. Note that throughout the paper we use the latest data published as of 4/1/2013. Thus, for instance, GDP data are from the March 2014 release.

${ }^{2}$ See Bernanke (2000) and Ito and Mishkin (2006) among many others.

${ }^{3}$ See Reuters and Financial Times on "unlimited easing" and Reuters on Abe's threat.
} 
to reach this target in two years through open-ended asset purchases and a doubling of the monetary base (Bank of Japan, 2013b).

The second arrow is fiscal policy. In February 2013, the Diet passed a two percent of GDP "supplementary budget" (Ito, 2013), although the actual stimulus being carried out is much smaller than this headline number suggests. ${ }^{4}$ Our preferred measure of stimulus size compares the cyclically adjusted primary budget balance forecast by the IMF before Abe's fiscal measures were announced with that forecast in late 2013. This suggests actual stimulus in 2013 of one percent of GDP. ${ }^{5}$ This stimulus is dwarfed by tax increases. Consumption taxes rose from five to eight percent in April 2014 and will rise by a further two percentage points in October 2015 (Ito, 2013). Thus the IMF projects that the cyclically adjusted primary budget deficit will fall from 8.5 percent of potential GDP in 2013 to 6.0 percent in 2014 and 4.8 percent in 2015. Since the consumption tax was passed long before Abe took office -it passed the lower house of the Diet on June $26^{\text {th }} 2012$ - we treat it as separate from Abenomics. Unless otherwise noted, the effects of Abenomics that we report do not include the contractionary effects of the consumption tax increase. But our estimates suggest that the negative effects of the consumption tax increases are insufficiently large to change our qualitative conclusions.

The third arrow consists of structural reforms to increase Japan's potential GDP growth. The proposed reforms are thus far mostly vague, but include relaxations of labor market rigidities, less protection for farmers, and utility deregulation. ${ }^{6}$ These reforms may be made more credible by the Japanese government's part in the Trans-Pacific Partnership, which suggests a willingness to take on special interests. ${ }^{7}$

For substantive and pragmatic reasons, we focus primarily on the first arrow of Abenomics, the monetary policy regime change. Monetary policy is the most clearly defined element of Abenomics. It is also the newest and most radical. Abe's government is not the first to try fiscal

\footnotetext{
${ }^{4}$ Throughout the 1990s, actual fiscal stimulus also usually fell short of headline numbers (Posen, 1998).

${ }^{5}$ Abe's fiscal expansion was originally conceived of as a one-time program, but in October 2013 the Abe government announced another one percent of GDP supplementary budget to offset adverse effects from mediumrun fiscal consolidation. (See Davies (Financial Times), and IMF.) Like the previous expansionary measures, we suspect that the headline number is an overestimate of the actual spending that will occur.

${ }^{6}$ Economist.

${ }^{7}$ See Deardorff (2013) and Financial Times.
} 
stimulus or fiscal consolidation. ${ }^{8}$ And Abe's government is not the first to push for structural reforms. $^{9}$ By contrast, the Bank of Japan's current policies are a clear break from previous attempts at unconventional monetary policy. Japan's monetary policy is also likely to be the element of Abenomics of most interest to other countries. There are many recent examples of fiscal stimulus programs and attempts at structural reform. Monetary policy regime changes are less common and less well understood.

We begin our analysis in section 2 by considering Japan's recent macro history and the size of its current output gap. In order for monetary policy to be an effective stimulus, there must be substantial unused resources in the economy. Using three different approaches, we find that the current output gap is in fact quite large, in the range of 4.5 percent to 10 percent. Thus it can at least be hoped that demand side policies will have large effects.

In section 3, we consider Abenomics' effects in 2013. We start by examining the financial market response. Over the year, the yen fell 21 percent against the dollar, and the Nikkei 225 stock market index rose 57 percent. Measured by inflation swaps and surveys of professional forecasters, long-run inflation expectations in early 2014 were between 1 and 1.4 percent. Combined with a small decline in nominal interest rates, this means ten-year real interest rates have fallen roughly a percentage point. Inflation also responded as hoped. The twelve-month percent change in the CPI rose from negative 0.1 percent in December 2012 to positive 1.6 percent in December 2013. Much of this increase was driven by the effects of the weaker yen on imported energy and food, but even the CPI excluding food and energy rose over the year.

Growth was also decent. Year-over-year, 2013 output growth was 1.5 percent, 0.9 percentage points better than expected by professional forecasters in December 2012, before Abe took office. Statistical (VAR) forecast counterfactuals imply possibly larger effects of Abenomics on 2013 growth, on the order of 1.1 to 1.8 percentage points.

That Abenomics contributed to a good year in 2013 is clear. Less clear is how much expansionary monetary policy as opposed to one-off fiscal stimulus drove that growth. A clue

\footnotetext{
${ }^{8}$ Posen (1998) and Kuttner and Posen (2001) analyze Japanese fiscal policy in the 1990s.

${ }^{9}$ Hoshi and Kashyap (2011) discuss reforms made under the Koizumi administration.
} 
comes from the behavior of consumption. As we discuss in section 3.6, both the time path and composition of consumption strongly suggest that expansionary monetary policy accounts for a significant part of 2013 consumption growth, perhaps contributing as much as a percentage point to overall GDP growth.

In the medium and long-run, Abenomics, and Japan's new monetary policy in particular, is likely to continue to pass a cost-benefit test. The costs are likely to be small: the long-run inflation target is moderate and by paying interest on reserves the Bank of Japan would be able to contain future inflation even with its expanded balance sheet. Further, so long as the current cooperation with the government is maintained, any losses on the Bank of Japan's portfolio are unlikely to restrict its future policy choices. ${ }^{10}$ By contrast, the benefits both to output and the government budget are potentially large. But, as of yet, it appears unlikely that Abenomics will fully close the output gap.

In section 4, we look to four sources of evidence on the future effects of Abenomics: (1) forecasts from professional forecasters; (2) the stock market; (3) the analogy to the U.S. in 1933; and (4) new and old Keynesian models. Professional forecasts suggest that Abenomics has raised both the level and the growth rate of GDP. But the forecast gains are modest relative to the output gap. Excluding negative effects from the consumption tax increase, by 2022, GDP is forecast to be 3.1 percent above the no Abenomics baseline. ${ }^{11}$ Our reliance here on forecasts, as in our discussion of Abenomics' 2013 effects, may make some readers uneasy. Professional forecasters have no particular knowledge of the effects of a monetary regime change, and both professional and statistical forecasts come with large standard errors. We therefore consider a range of other evidence to determine if we should discount these forecasts. For instance, the stock markets' 2013 boom might seem to forecast larger gains. But a Campbell-Shiller decomposition shows that historically, the stock market has been a poor predictor of dividend

\footnotetext{
${ }^{10}$ See Hall and Reis (2013) for a discussion of these central bank solvency concerns. As discussed further in section 4.6, this issue suggests that implementing Abenomics could be difficult in other countries where there is less cooperation between the government and the central bank.

11 Taking account of the consumption tax increase would not qualitatively change this conclusion. In section 4.5, we show that forecast revisions imply that the consumption tax will subtract 0.5 percentage points from growth in 2014 and just 0.1 percentage points from growth in 2015.
} 
growth and thus likely an even worse predictor of GDP growth. Also initially suggesting optimism is the success of Franklin Roosevelt's monetary regime change in spring 1933. This is often taken as an example of the large potential effects of a monetary regime shift. So far, however, the effects of Abenomics have been an order of magnitude smaller.

Finally, a natural approach is to combine a financial market measure of the real interest rate change with a model based estimate of the effect of the real interest rate on output. Using a conventionally calibrated new Keynesian model, this approach suggests that by now (April 2014) output ought to have risen 5 to 10 percent. Again this prediction is at odds with Japan's more modest experience in 2013. Overall, we read the evidence from the stock market, history, and Keynesian models as insufficiently convincing to discount the more moderate effects implied by professional forecasts.

An important caveat to all our analysis is that we treat Abenomics as is. That is, we take as given the effect of Abe's policies on expected inflation and expected future output. This means we are analyzing a policy that has a stated goal of two percent inflation but has not yet convinced the public that the goal will be achieved. Market- and survey-based inflation forecasts suggest that the two percent inflation target is not (yet) credible, presumably because there is some probability that Abe or the Bank of Japan will change course. Thus we are measuring the effects of a two percent inflation target times the probability that the target is achieved. We argue in section 5 that the Bank of Japan's credibility problems are likely a product of its past actions and the interaction of Japan's demographics and non-inflation-indexed pensions.

The current lack of credibility means that if the Bank of Japan does succeed in raising inflation expectations to two percent, output effects are likely to be larger than current indicators suggest. Holding nominal rates fixed, full credibility would lead to another 0.7 percentage point decline in the real interest rate. We would therefore expect another short-run boost to GDP commensurate with our estimate of the monetary policy contribution to 2013 GDP growth. In the medium-run the gains are likely to be even larger. But with current data it is difficult to produce an estimate of this effect. For instance, long-run forecast revisions do not allow us to distinguish monetary effects from structural reform expectations. In section 6 we do, 
however, offer a brief roadmap to interpret future data releases and forecasts revisions. We provide guidance to help distinguish between the effects of the monetary and structural reform channel going forward.

\section{Context}

2.1 A brief history In the 1980s, Japan's economy was the envy of other nations: GDP had been growing rapidly for decades, the stock and property markets were booming, and Japanese production techniques were widely regarded as superior. ${ }^{12}$ This all changed in the 1990s. From December 1989 to August 1992, the Nikkei 225 fell almost 60 percent. Land prices in six large Japanese cities fell by 50 percent from 1991 to 1996 and continued to decline thereafter. The fallout from the bursting of these asset bubbles dragged down the economy. Economists have often criticized the Bank of Japan for not responding more quickly to these asset price declines and the resulting economic slowdown. By 1996, the Bank of Japan found itself effectively stuck at the zero lower bound on nominal interest rates. Thus the Japanese experience in the 1990s bears remarkable similarities to the period since 2008 in the U.S. and Europe.

Panel A of table 1 summarizes this story. ${ }^{13}$ After growing rapidly until 1991, annual Japanese real GDP growth slowed to roughly one percent. Inflation fell to near zero, with prices falling most years after 1998. Nominal interest rates fell more than inflation. To U.S. observers, the Japanese unemployment rate remained puzzlingly low. Its peak during the 200809 recession was 5.5 percent. But this reflects particular Japanese labor market institutions. Many Japanese workers have de facto lifetime tenure in their jobs (Kato, 2001). Thus when output falls, they remain employed.

Japan's economy was hard hit by the 2008 recession. From its peak in the first quarter of 2008 to its trough in the first quarter of 2009, output fell 9.2 percent. Since then, recovery has been incomplete. GDP in the last quarter of 2013 was still below that in the first quarter of 2008. In part this is because a nascent recovery in 2010 was reversed in 2011: GDP growth swung from +4.7 percent in 2010 to -0.5 percent in 2011. A major culprit was the devastating

\footnotetext{
${ }^{12}$ For background on the Japanese economy before 1990, see Ito (1992).

${ }^{13}$ This table is a deliberate updating of Krugman (1998), table 4.
} 
Table 1 - Macro summary statistics

\begin{tabular}{lcccc}
\hline \hline Panel A: Raw data & \multicolumn{3}{c}{} \\
\hline Year & $\begin{array}{c}\text { Real GDP } \\
\text { growth } \\
(\% \text { change })\end{array}$ & $\begin{array}{c}\text { Unemployment } \\
\text { rate } \\
(\%)\end{array}$ & $\begin{array}{c}\text { CPI } \\
\text { inflation } \\
(\%)\end{array}$ & $\begin{array}{c}\text { Money market } \\
\text { interest rate } \\
(\%)\end{array}$ \\
\hline $1974-1992$ average & 4.0 & 2.3 & 4.8 & 6.8 \\
$1993-2007$ average & 1.1 & 4.1 & 0.1 & 0.6 \\
$2008-2012$ average & -0.2 & 4.6 & -0.2 & 0.2 \\
\hline
\end{tabular}

Panel B: Adjusted for working age population

\begin{tabular}{|c|c|c|c|c|c|c|}
\hline \multirow[t]{2}{*}{ Year } & \multicolumn{2}{|c|}{$\begin{array}{l}\text { Real GDP per } \\
\text { person age } 15-64 \\
\text { (\% change) }\end{array}$} & \multicolumn{2}{|c|}{$\begin{array}{l}\text { Multifactor } \\
\text { productivity } \\
\text { (\% change) }\end{array}$} & \multicolumn{2}{|c|}{$\begin{array}{c}\text { Employment / } \\
\text { pop. age 15-64 } \\
(\%)\end{array}$} \\
\hline & Japan & U.S. & Japan & U.S. & Japan & U.S. \\
\hline 1974-1992 average & 3.1 & 1.5 & - & - & 67.4 & 68.1 \\
\hline 1993-2007 average & 1.4 & 1.9 & 0.9 & 1.2 & 69.3 & 72.5 \\
\hline 2008-2012 average & 0.4 & 0.2 & $0.3^{*}$ & $0.8^{*}$ & 70.8 & 67.8 \\
\hline
\end{tabular}

Sources for Japanese and U.S. data: See data appendix. ${ }^{*} 2008-2011$ average.

March 11 ${ }^{\text {th }}$, 2011 Tohoku earthquake and tsunami. This disaster killed almost 20,000 people and destroyed 275,000 homes (Schnell and Weinstein, 2012).

Poor headline GDP numbers in part reflect Japan's low birth rate. The Japanese National Institute of Population and Social Security Research projects that the Japanese population peaked in 2010 and has since begun declining. ${ }^{14}$ Thus GDP per capita growth now exceeds GDP growth. Furthermore, as Japan's population has aged, the growth rate of the working age population has generally been below that of the population as a whole. The number of people age 15 to 64 peaked in 1995 at 87 million; by 2010 there were only 81 million. Given these demographic trends, it is unreasonable to expect Japanese GDP growth to match that in countries with growing populations, like the U.S.

A crude way to correct for the growth consequences of Japan's demographics is to measure the growth of GDP per person age 15 to 64 . Columns 1 and 2 of panel B in table 1 do this for Japan and the U.S. since 1974. With this adjustment, the Japanese growth slowdown is less pronounced. And the Japanese economy's performance relative to the U.S. is better than some popular accounts would suggest. This is not to say that Japan did well. From 1992 to

\footnotetext{
${ }^{14}$ See http://www.ipss.go.jp/p-info/e/psj2012/PSJ2012.asp.
} 
2007 GDP per working age person grew 0.5 percentage points more slowly in Japan than in the U.S. A comparison of multifactor productivity has similar implications: from 1992 to 2007 multifactor productivity grew 0.3 percentage points more slowly in Japan. Thus as of 2012, Japan's PPP-adjusted real GDP per person age 15 to 64 was only 71 percent of that in the U.S. Columns 5 and 6 of panel B in table 1 compare the employment to population ratio for people age 15 to 64 in the two countries. This ratio was lower in Japan than in the U.S. prior to the 2008 recession. But during the recession, the employment to population ratio fell sharply in the U.S. while remaining fairly stable in Japan. So as of 2012, more of the working age population in Japan is employed.

Slow growth, an enormous natural disaster, and a shrinking population are not the only headwinds facing the Japanese economy. Japan also has a large sovereign debt burden. The gross debt to GDP ratio rose from 66 percent in 1991 to 244 percent today. Net debt in 2013 is an only somewhat less staggering 140 percent of GDP. This debt burden has thus far coexisted with extraordinarily low nominal and real interest rates. As of March $31^{\text {st }}$, 2014 the nominal interest rate on ten-year Japanese government bonds was 0.6 percent while expected ten-year inflation (from inflation swaps) was 1.3 percent. Yet some economists fear that Japan is close to the point at which investors will no longer tolerate an increasing debt to GDP ratio (e.g., Hoshi and Ito, 2012). This debt burden adds to the sense of many that the past twenty years were two "lost decades."

2.2 The output gap Japan's two decade stagnation was likely a product of both demand and supply side problems. A clear separation is difficult. Financial sector problems, for instance, affect both investment demand and firm marginal costs. But some decomposition is important; if Japan's problems were entirely the result of changes to potential output, then a monetary regime change could have little real effect. In order to know what a demand side policy can achieve, we need to know the size of Japan's output gap.

Official estimates of Japan's output gap are small. In its October 2013 World Economic Outlook, the IMF estimated that Japan's 2013 output gap would be -0.9 percent. In its November 
2013 Economic Outlook, the OECD estimated that Japan's 2013 output gap would be positive 0.1 percent. These measures suggest that there is little role for demand side policy in Japan: neither fiscal stimulus nor lower real interest rates will raise output if supply constraints are binding. In this case, the only arrow of Abenomics that matters is the third.

The IMF and OECD measures, however, almost certainly have difficulty with Japan's two decade stagnation. Prolonged slumps can mean that conventional estimates of potential output which use, for instance, a Hodrick-Prescott filter, interpret the slowdown in actual growth to have been primarily a slowdown in potential output growth (Krugman, 1998). While the IMF currently uses a production function approach, not a Hodrick-Prescott filter, to measure Japanese potential output, its methods suffer from a similar problem: the IMF's potential output measure closely tracks forecast and actual output (figure 1(a)). ${ }^{15}$ Between 2008 and 2013, the IMF's estimate of 2009 potential output growth fell from 1.7 percent to 0.3 percent.

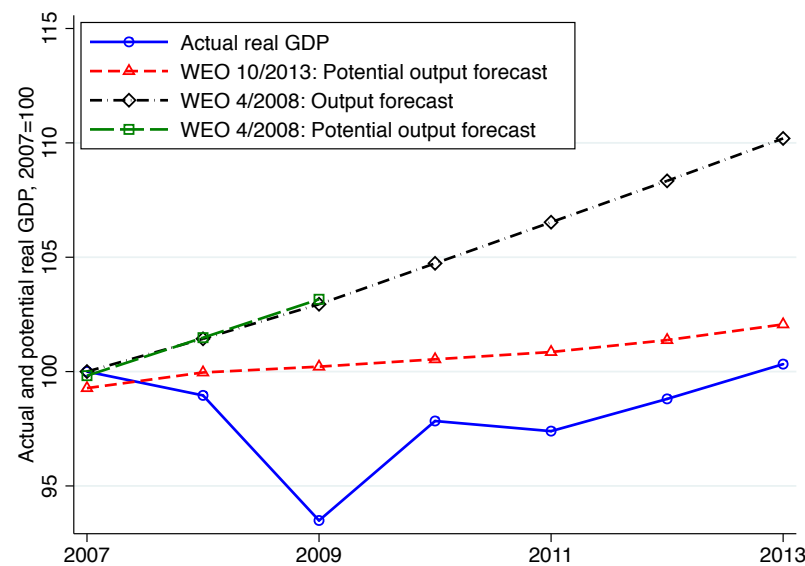

(a) IMF forecasts of actual and potential output

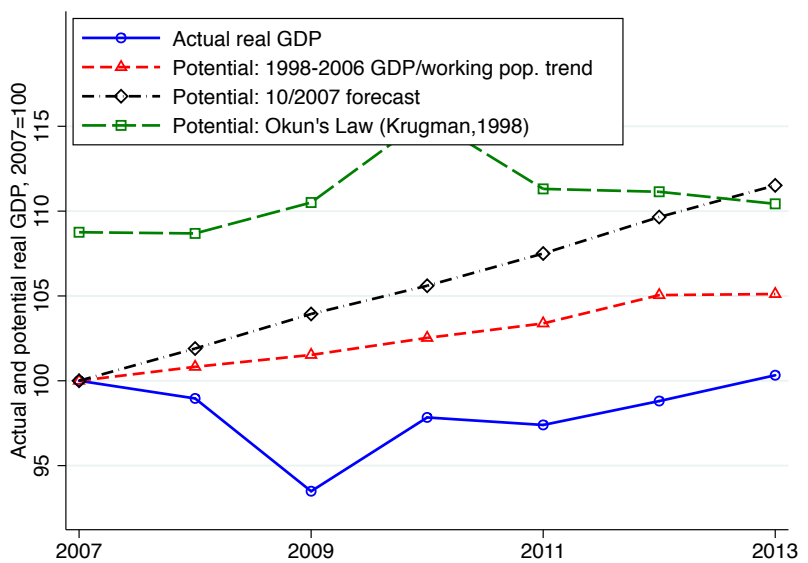

(b) Trend and forecast potential output estimates

Figure 1 - Japanese actual and potential output.

A large part of this revision to potential likely comes from lower investment. ${ }^{16}$ A smaller capital stock certainly diminishes the level of output achievable at a given point in time, but over several years, investment shortfalls can be made up. So it is not obvious how much a

\footnotetext{
${ }^{15}$ The IMF publishes a forecast for actual GDP and the output gap as a percent of potential in the World Economic Outlook. We computed the implied level of potential output as $Y_{\text {potential }}=\frac{Y_{\text {actual }}}{1+\text { gap }}$.

${ }^{16}$ Lower investment explains most of the downward revision to the Congressional Budget Office's estimates of U.S. potential output (Jacobson and Occhino, 2013).
} 
period of lower investment should affect one's view of what a demand side policy can achieve in the medium-run. A historical example may clarify. Investment was low in the U.S. throughout the 1930s. But in part because of stimulative monetary policy after 1933 and stimulative fiscal policy during World War Two, the Great Depression does not appear to have lowered potential or actual U.S. output in 1950.

Hysteresis effects in the labor market, such as high long-term unemployment and early retirement, may also lower potential. But it seems likely that a prolonged boom could reverse many of these effects. Ball (2009) finds that large demand expansions are associated with declines in the natural rate of unemployment and, by implication, increases in potential output.

For the purpose of evaluating the potential effects of a prolonged demand side policy, we believe the correct measure of potential output conditions on resources having been close to fully-employed for some time. This is unlike the IMF which measures potential output conditional on all resources being employed at their current capacity. Thus we do not believe that the IMF measure - an output gap of -0.9 percent - is a good indicator of what sustained expansionary monetary policy should aim for in Japan. We suspect that if Japanese output growth is high for several years, the IMF estimate of potential output will rise. If one disagrees with this assessment, one may find the official, small measures of Japan's output gap unproblematic. In that case, one would expect little from monetary policy other than price effects. Presumably, like us, Japanese officials do not hold this view; if they did, it is unclear why they would have gone to the effort of staging a monetary regime shift.

We are not the first to struggle with estimating Japan's output gap. Krugman (1998) also argued that official estimates of Japan's output gap were too small. Instead of relying on official figures, he combines an estimate of Japan's natural rate of unemployment with an estimate of the Okun's law coefficient in Japan. Krugman estimates Japan's natural rate of unemployment as 2.5 percent. This was Japan's average unemployment rate in the decade from 1982 through 1991. Again using data from the 1980s, Krugman argues that Japan's Okun's law coefficient is roughly six. These two estimates, combined with Japan's 2013 unemployment rate (4.0 percent), suggest that the output gap in 2013 was roughly $6 \times(4-2.5)=9$ percent. 
Of course the unemployment rate in the 1980s may no longer be a good indicator of Japan's natural rate of unemployment. Even ignoring hysteresis effects, demographic changes, for instance, have likely changed the natural rate. ${ }^{17}$ Another approach to estimating potential output is to assume that output continues to grow at its pre-depression trend. This is the approach taken by Romer (1999) for the Great Depression. We use Japan's trend growth rate of output per working age person from 1998 to 2006 to obtain a measure of Japan's current output gap. 1998 and 2006 are sensible start and end dates since the unemployment rate was the same in these two years. Normalizing the trend by the working age population incorporates Japan's changing demographics since the 1990s. Figure 1(b) shows this trend along with actual output. We assume that output was at potential in 2007. This suggests a 2013 output gap of 4.6 percent. Many observers would, however, argue that output in 2007 was below potential. Okun's law implies that the 2007 output gap was in fact 8 percent (figure 1(b)). Thus our trend-based measure is biased towards underestimating Japan's current output gap. Bias in the other direction comes from effects of the 2008 recession and the 2011 tsunami on potential output. As discussed above, it is not obvious that a potential output measure that responds strongly to recessions is correct for our purposes. But the 2011 tsunami raises separate issues. This disaster not only caused enormous physical destruction, it also led to the shutdown of all Japanese nuclear power plants. This raised energy prices, with economy-wide negative effects on aggregate supply (Schnell and Weinstein, 2012). Unfortunately, quantifying the effect on potential output is difficult. A hint that it was small comes from the IMF's October 2013 World Economic Outlook, which shows no slowdown in potential output growth between 2010 and 2011.

A final way to measure the output gap is to see what professional forecasters expected longrun growth to be in 2007. Absent any large and expected demand side policies, these forecasts

\footnotetext{
${ }^{17}$ Unfortunately, recent data are not well suited to estimating Japan's natural rate: Japan's inflation rate over the past several years has been negative but not falling. This has unclear implications for the natural rate. For instance, Ball (2006) and Blanchard (2000) suggest that the Phillips curve relationship in Japan may be between the level of inflation and slack rather than the more conventional relationship between changes in the inflation rate and slack. The challenges to estimating the natural rate of unemployment in Japan now are similar to those that plague any such calculation for the U.S. in the 1930s. Just as in Japan now, low output and employment in the 1930s U.S. coexisted with increases in the inflation rate (Romer, 1999).
} 
are likely to measure observers' best guess of trend growth. Like the previous measure, this ignores any effects of the 2008 recession or the 2011 tsunami on potential output, but it may also suffer from the opposite bias, in that forecasters may not have believed that the economy would return to potential in 2013. In any case, this forecast is also shown in figure $1(\mathrm{~b})$. It suggests a 2013 gap of 10 percent, similar to that using the Okun's law method. Therefore these three measures suggest a large output gap in Japan, in the range of 4.5 to 10 percent.

\section{Impact}

In this section, we examine the effect of Abenomics on the Japanese economy in 2013. First, we consider how financial markets reacted. We focus on interest rates and the exchange rate. Since models suggest that Abenomics will work by lowering the real interest rate, ${ }^{18}$ and to a lesser extent by weakening the yen, these are relevant intermediate indicators of success. We next examine how actual inflation and output growth have responded.

3.1 Financial markets Figure 2(a) shows nominal interest rates in Japan since 2007. Twoyear government bond yields were near zero before Abe took office, and they have changed little since. By contrast, both ten-year and thirty-year government bond yields have fallen. As of March $31^{\text {st }}$, 2014, the yield on ten-year Japanese government bonds was 0.64 percent, 21 basis points below the average yield in 2012. Thus any expectations of inflation induced by the Bank of Japan have not led to higher nominal interest rates, even over quite long horizons.

Given small changes in nominal interest rates, expected inflation has been the primary determinant of movements in real interest rates. Unfortunately, there is no ideal measure of Japanese expected inflation. The market for inflation-linked Japanese government bonds is too thin for these prices to be reliable (Mandel and Barnes, 2013). As a market measure of Japanese inflation expectations, we instead use inflation swap rates. These are also not ideal, since they are illiquid, and they incorporate potentially time-varying risk premia (Mandel and Barnes, 2013). But we are reassured by the similarity of this measure of inflation expectations with that derived from surveys of professional forecasters. In October 2012, the Consensus

\footnotetext{
${ }^{18}$ This is the main channel emphasized in old and new Keynesian models (Romer, 2012; Woodford, 2003).
} 


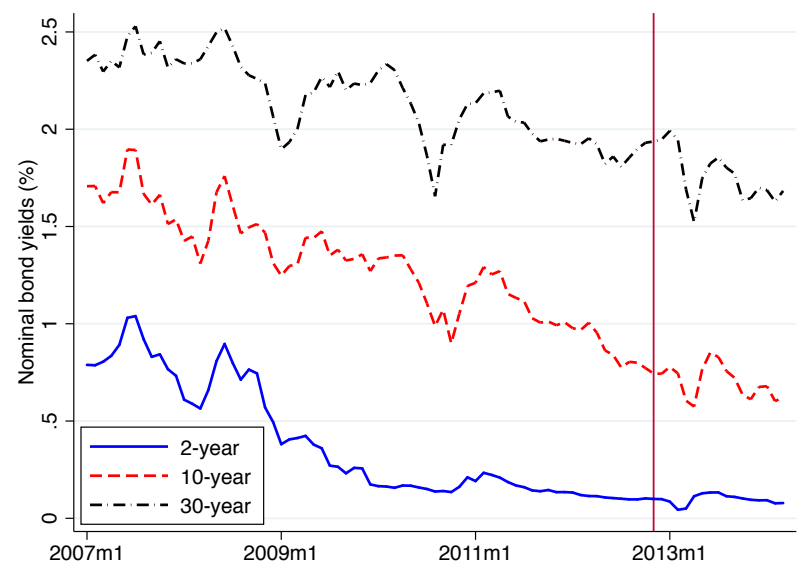

(a) Nominal bond yields

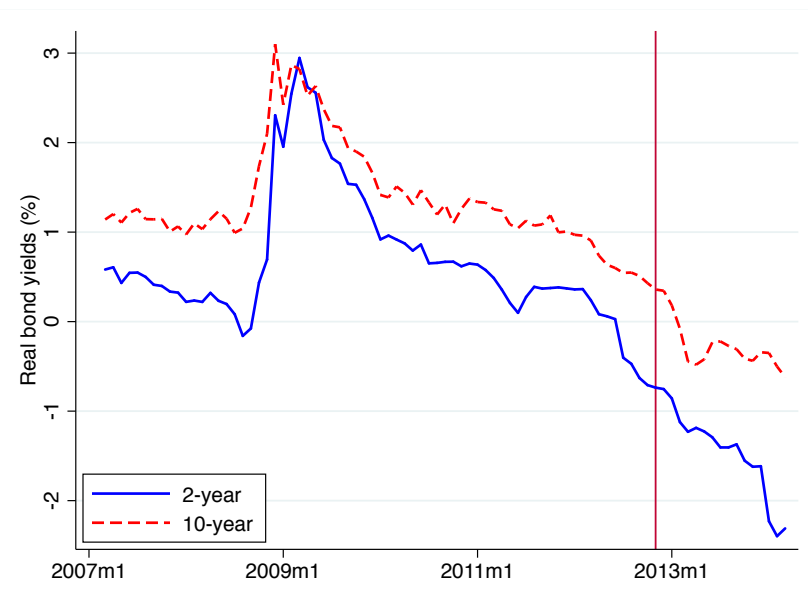

(c) Real bond yields

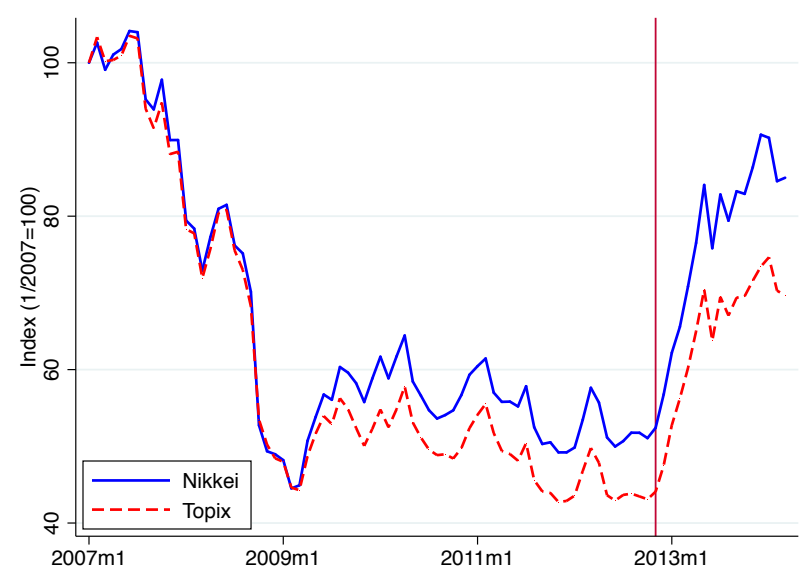

(e) The stock market

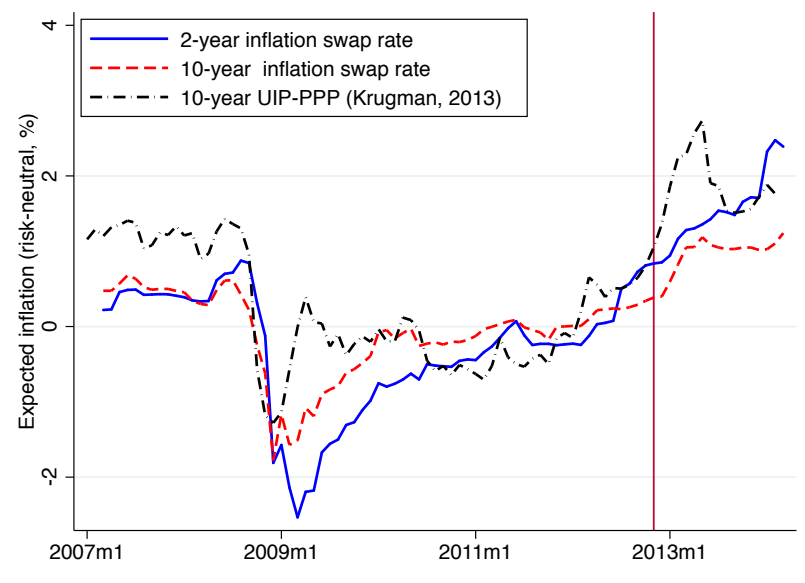

(b) Market inflation forecasts

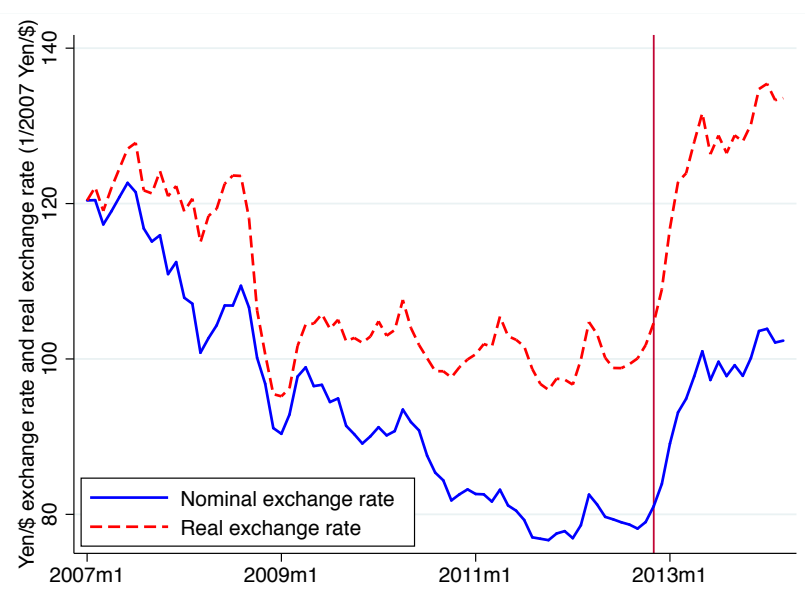

(d) Exchange rates

Figure 2 - Abenomics' financial market effects. Abenomics begins at the red line, November 2012. Real bond yields are calculated as the difference between nominal bond yields and inflation swap rates. Source: See data appendix. 
Economics survey of professional forecasters showed average annual expected inflation in 2013 and 2014 of 0.65 percent. In the same month, the yield on two-year inflation swaps averaged 0.8 percent. A year later, in October 2013, two-year inflation expectations from Consensus Economics had risen to 1.8 percent, while the yield on two-year inflation swaps had risen to 1.7 percent. $^{19}$

An alternative approach to measuring Japanese inflation expectations, suggested by Krugman (2013) (following Mandel and Barnes, 2013), is to use uncovered real interest rate parity and the purchasing power parity (PPP) condition to estimate Japanese inflation expectations using U.S. inflation-linked bonds (TIPS). ${ }^{20}$ This calculation requires taking a stand on when the yen-dollar real exchange rate was consistent with purchasing power parity. We follow Krugman (2013) in assuming the equilibrium exchange rate was that in January 2010. Uncertainty about this leads to uncertainty about the level of expected inflation. But we are primarily interested in the change after Abenomics began.

Figure 2(b) shows the behavior of inflation swaps and this alternative measure of inflation expectations. All measures of inflation expectations were rising before Abenomics and rose rapidly in the first half of 2013. Between October 2012 and April 2013, 10-year inflation swap rates rose from 0.3 percent to 1.1 percent. The interest rate parity measure of inflation expectations rose somewhat more. In October 2012 it was 0.8 percent; in January 2014, it was 1.9 percent. Since, as we describe below, long-run inflation expectations of professional forecasters are well below two percent, the interest rate parity measure - 1.9 percent-may overestimate the level of expected inflation. But we see it as confirming the basic insight from our other measures: that Abenomics raised long-term inflation expectations in Japan by roughly a percentage point.

\footnotetext{
${ }^{19}$ At longer horizons, there is a larger difference between the level of inflation expectations from Consensus Economics and that from inflation swaps. But the changes have been similar.

${ }^{20}$ Uncovered real interest rate parity implies that $r_{\text {japan }}=r_{u s}+\% \Delta e$, where $r$ is the real interest rate, $e$ is the real exchange rate, the price of U.S. goods in terms of Japanese goods, and $\% \Delta e$ is the depreciation required for purchasing power parity to hold. Expressing the real interest rate as the difference between the nominal interest rate $(i)$ and expected inflation, this implies that $\pi_{\text {japan }}^{e}=i_{\text {japan }}-i_{u s}+\pi_{u s}^{e}-\% \Delta e$. Following Krugman (2013), we assume that the real exchange rate will take ten years to get back to its January 2010 value. We calculate the real exchange rate as $\frac{E P^{*}}{P}$ where $E$ is the yen-dollar exchange rate, $P^{*}$ is the seasonally adjusted U.S. CPI and $P$ is the seasonally adjusted Japanese CPI.
} 
The combination of steady or falling nominal interest rates with increasing inflation expectations has meant a precipitous decline in real interest rates (figure 2(c)). We measure the real interest rate as the difference between the nominal government bond yield and the inflation swap yield. Between October 2012 and March 2014, the two-year real interest rate fell 1.6 percentage points, and the ten-year real interest rate fell 1.1 percentage points. The larger decline in the two-year real interest rate was in part driven by the upcoming consumption tax increases, which increased expected inflation.

The Bank of Japan's higher inflation target is likely to affect the economy primarily through its effect on real interest rates. But an important, secondary channel is the exchange rate. Figure 2(d) shows the behavior of the yen-dollar exchange rate since 2007. After averaging 79 yen per dollar in the first ten months of 2012, the yen weakened rapidly, reaching 103 yen per dollar in May 2013. Prices changed little over this short period in Japan or its major trading partners, so the Bank for International Settlements broad effective real exchange rate index moved essentially one-for-one with the nominal rate (figure $2(\mathrm{~d})$ ).

Abenomics also had dramatic effects on the stock market. Figure 2(e) shows the Nikkei 225 and the broader Topix index. Between October 2012 and May 2013, the Nikkei rose 65 percent and the Topix 63 percent. Higher asset prices are one channel through which Abenomics may help the Japanese economy. Most obviously, higher stock prices lead to more consumption and investment. The stock price increase has also been taken by some to be an implicit forecast of large long-run effects of Abenomics. We consider this argument in section 4.2.

We would like to know how much these changes reflect the effects of Abenomics and monetary policy in particular. One source of evidence is announcement effects: if the Bank of Japan's new-found resolve to raise inflation drove the 2013 movements of interest rates, exchange rates, and the stock market, we should see large immediate reactions when the Bank of Japan announced its new policies.

Table 2 shows the change in several financial market indicators in a 24-hour window around dates of news about the Bank of Japan's new monetary policy. ${ }^{21}$ On the first date, November

\footnotetext{
${ }^{21}$ Note that though inflation swap yields are shown in the table, their general lack of liquidity makes non-
} 
$15^{\text {th }}$, 2012, then-candidate Abe argued that the Bank of Japan should conduct "unlimited easing." 22 There was little change in nominal bond yields or inflation swap rates, but the yen weakened by more than one percent and stock prices rose more than two percent. On the second date, January $22^{\text {nd }}$, 2013, the Bank of Japan committed itself to a two percent inflation target (Bank of Japan, 2013a). Since Abe had already called on the Bank of Japan to raise its inflation target, this announcement had little new information. And despite Abe's support of the Bank of Japan's new target, there was a widespread view that it lacked credibility. The Wall Street Journal quoted the economist Joseph Gagnon saying: "It's meaningless . . . The Bank of Japan is very good at telling politicians it's going to do a lot, and then doing nothing." 23 Consistent with this interpretation, the yen strengthened and the Topix stock market index fell nearly half a percent. Yields on government bonds and inflation swaps were essentially unchanged.

Table 2 - Announcement effects

\begin{tabular}{|c|c|c|c|c|c|c|c|}
\hline \multirow[t]{3}{*}{ Date } & \multicolumn{3}{|c|}{ JGB } & \multicolumn{2}{|c|}{ Inflation swap } & Yen $/ \$$ & TOPIX \\
\hline & $2-\mathrm{yr}$ & 10-yr & $30-y r$ & 2 -yr & $10-\mathrm{yr}$ & \multirow{2}{*}{\multicolumn{2}{|c|}{$\%$ change }} \\
\hline & \multicolumn{3}{|c|}{ bp change } & \multicolumn{2}{|c|}{ bp change } & & \\
\hline $11 / 15 / 12$ & -0.5 & -0.9 & 2.8 & 0.5 & 0.0 & 1.15 & 2.09 \\
\hline $1 / 22 / 13$ & -0.1 & -0.8 & -0.1 & -0.7 & 3.2 & -0.99 & -0.44 \\
\hline $2 / 5 / 13$ & -1.2 & -2.9 & -2.2 & 5.3 & 15.9 & 1.36 & 1.37 \\
\hline $4 / 4 / 13$ & 0.3 & -11.4 & -21.7 & 0.0 & 0.0 & 3.55 & 2.70 \\
\hline
\end{tabular}

Notes: One-day changes in Japanese government bond (JGB) yields, inflation swaps, the nominal yen-dollar exchange rate, and the Topix index following announcements or events on a given date. The dates are selected as follows: on 11/15/12 then-candidate Shinzo Abe calls for "unlimited" easing; 1/22/13 is the Bank of Japan's inflation target announcement; $2 / 5 / 13$ is the resignation announcement of the Bank of Japan governor Masaaki Shirakawa (we use a 2-day change since it is unclear whether markets had already closed); $4 / 4 / 13$ is the announcement date of the Bank of Japan's new quantitative and qualitative monetary easing policy.

The third date is February $5^{\text {th }}$, 2013, when the Bank of Japan governor, Masaaki Shirakawa, announced that he would resign early. This was interpreted as evidence that the Bank of Japan would soon be led by someone more sympathetic to bold monetary actions. ${ }^{24}$ Government bond

\footnotetext{
responses difficult to interpret. Inflation swap yields often only change once every few days.

${ }^{22}$ Financial Times.

${ }^{23}$ Wall Street Journal.

${ }^{24}$ Financial Times.
} 
yields fell, inflation swap yields rose, the yen weakened, and stock prices rose. ${ }^{25}$

The Bank of Japan finally specified actions to reach its two percent inflation target on April $4^{t h}, 2013$, the last date in table 2. These actions were dubbed "quantitative and qualitative monetary easing" (QQME). They included a commitment to double the monetary base and the Bank of Japan's holdings of Japanese government bonds (JGBs) in two years. The statement quite deliberately emphasized the newness of the policies; it referred to a "new phase of monetary easing in terms of quantity and quality" (Bank of Japan, 2013b).

Markets were jubilant. Ten-year government bond yields fell 11 basis points, and thirtyyear yields fell 22 basis points. This was the largest one-day decline in the thirty-year yield in almost a decade. ${ }^{26}$ Inflation swap yields were unchanged that day, presumably reflecting a lack of trading volume. But in their next quote, both the two-year and ten-year inflation swap yields rose 4 basis points. The April $4^{\text {th }}$ announcement also had sizable effects on the yen and the stock market. The 3.6 percent decline in the yen's value against the dollar was the fourth largest one-day depreciation since 1978. Thus a comparison of the January $22^{\text {nd }}$ and April $4^{\text {th }}$ announcements strongly suggests that the mere announcement of an inflation target had much smaller effects than the announcement of actions which could make the target credible. ${ }^{27}$ In any case, the announcement effects suggest that monetary policy was an important driver of financial market behavior in 2013 .

3.2 Inflation We now turn to an examination of actual inflation in 2013. Figure 3(a) shows three measures of Japanese inflation, the CPI, the CPI excluding fresh food and energy, and the GDP deflator. The overall CPI has risen since March 2013. The twelve-month percent change from December 2012 to December 2013 was 1.6 percent. This was the highest inflation rate in Japan since the 2008 energy price shock. Year-over-year CPI inflation was 0.4 percent, 0.6 percentage points above the December 2012 Consensus Forecast. Thus Abenomics ended deflation in 2013. But a concern is that much of this inflation may have been driven by a

\footnotetext{
${ }^{25}$ It is unclear whether this announcement came while markets were still open, so we use a two-day window.

${ }^{26}$ Based on an analysis of forward rate movements on April $4^{\text {th }}$, Rogers, Scotti, and Wright (2014) argue that most of this movement in bond yields was due to the effect of this announcement on term premia.

${ }^{27}$ See Kuttner and Posen (2001) for a discussion of the effects of earlier Bank of Japan announcements. For more discussion of the effects of Abenomics announcements, see Ueda (2013).
} 
weaker yen and hence may not continue.

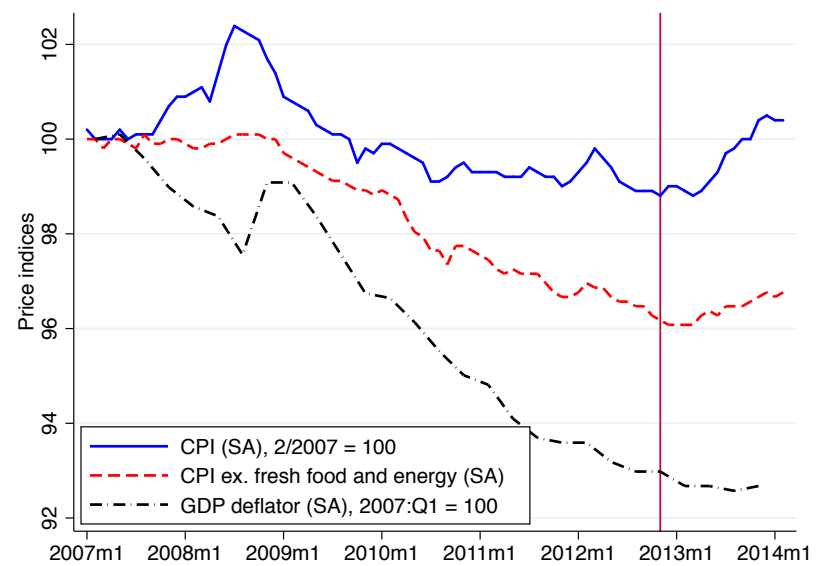

(a) CPI data

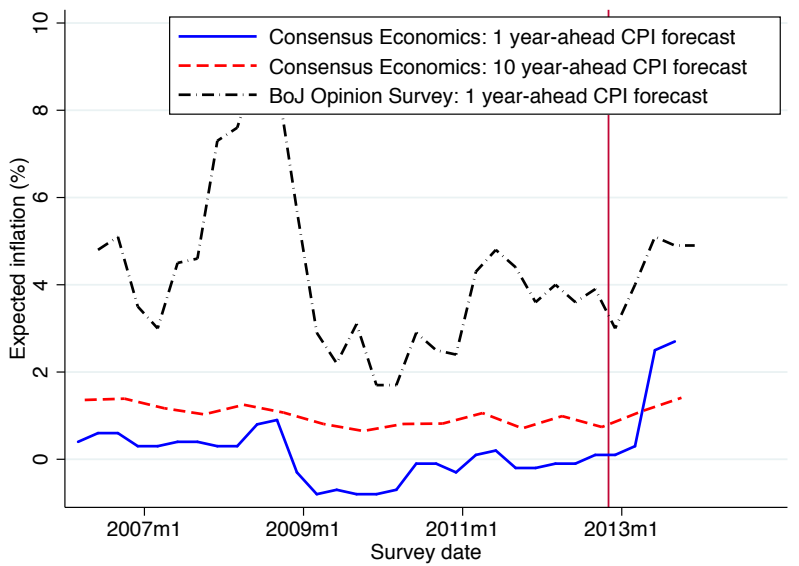

(b) Survey inflation forecasts

Figure 3 - Japanese actual and expected inflation. Abenomics begins at the vertical line, November 2012. Source: See data appendix.

Energy and fresh food prices are especially sensitive to the yen's value. The so-called coreCPI strips out both these categories. Figure 3(a) shows that this measure of the CPI has also risen since March 2013, but by much less. In the twelve months from December 2012 to December 2013, it rose 0.7 percent. A final measure of inflation, which has the advantage of excluding all imports, is the GDP deflator. After years of steady decline, the GDP deflator was flat through most of 2013 (figure 3(a)). In part this was because over the four quarters of 2013, the deflator for exports rose almost 10 percent. Notably, both the CPI and GDP deflator have risen more in 2013 than they did from early 2005 to early 2007 when the yen depreciated by nearly 20 percent. While the comparison is imperfect because the 2013 depreciation was more rapid, it does suggest that Abenomics' effect on prices goes beyond pass-through. Further, a yen depreciation will exert only a temporary effect on CPI inflation as relative prices adjust. So the rise in long-run CPI inflation expectations suggests that more persistent (domestic) factors are at play. Thus to the extent that these inflation expectations prove accurate, we also expect the GDP deflator to rise going forward.

Positive inflation is not yet firmly established, however. In January 2014, both the overall CPI and the CPI excluding food and energy fell. Consistent positive inflation likely requires 
increases in nominal wages. Here the news is somewhat encouraging. Including bonuses, nominal hourly earnings rose 0.4 percent from December 2012 through December $2013 .^{28}$ Many workers' wages are set in annual spring negotiations between unions and employers. As this paper was being finalized, these negotiations were ending. Early reports suggest that many firms have agreed to small nominal wage increases. Toyota, for instance, agreed to raise wages by 0.8 percent. $^{29}$ While any nominal wage increases are encouraging, thus far these have been insufficient to prevent inflation from eroding real wages.

The extent to which firms grant workers wage increases depends in large part on their inflation expectations. We consider two proxies for firm inflation expectations in Japan: (1) the expectations of professional forecasters and (2) the expectations of households. Professional forecasters are likely to provide a useful proxy for the inflation expectations of large multinational firms. Such firms have the resources either to employ forecasters themselves or to seek outside professional opinions. ${ }^{30}$ By contrast, Coibion and Gorodnichenko (2013) argue that household inflation expectations are a good proxy for smaller firms' expectations.

Figure 3(b) shows one-year-ahead and ten-year ahead inflation expectations of professional forecasters from Consensus Economics, as well as one-year-ahead household inflation expectations from the Bank of Japan opinion survey. ${ }^{31}$ A surprising feature of these data is the level of inflation forecast by Japanese households. Respondents to the opinion survey generally forecast more than four percent inflation over the next year. Households also often say that inflation over the past year exceeded four percent, even though Japan has not experienced four percent year-on-year inflation since 1981. For our purposes, however, what matters most is the change in these expectations.

Both household and professional inflation expectations have risen since late 2012 (figure

\footnotetext{
${ }^{28}$ Total cash earnings rose 0.5 percent while hours rose 0.1 percent.

${ }^{29}$ See New York Times. Olivei and Tenreyro (2010) discuss how synchronized wage setting affects monetary policy effectiveness in Japan.

${ }^{30}$ As noted above, the changes in market inflation expectations from inflation swaps and inflation expectations by professional forecasters have been very similar.

${ }^{31}$ The Bank of Japan opinion survey is a poll of approximately 4000 randomly-sampled individuals above age 20. Individuals are sent a questionnaire in the mail, and the response rate, though variable, tends to be around 55 percent. See Bank of Japan Opinion Survey.
} 
3(b)). The one-year inflation forecast from professional forecasters rose particularly fast in early 2013, but this likely reflects the April 2014 consumption tax hike. Respondents to the Bank of Japan opinion survey were instructed to ignore the consumption tax increase in forming their inflation expectations, but professional forecasters received no such instruction. ${ }^{32}$

While the change in inflation expectations is encouraging, the level of inflation forecast by professional forecasters, like inflation swap rates, suggests that the Bank of Japan's target is not (yet) fully credible. As of October 2013, professional forecasters expected 1.4 percent annual inflation over the next ten years. (As of March 2014, ten-year inflation swap yields are 1.2 percent, figure 2(b).) This implies that the output effects we discuss below are the effects of an imperfectly credible monetary policy change.

3.3 Comparison to Quantitative Easing We have argued that Japan's recent monetary policy announcements and actions had large effects on financial markets and both actual and expected inflation. These effects are strikingly different from those of the Bank of Japan's 2001 to 2006 experiment with quantitative easing (QE). What is the Bank of Japan doing now that it did not do in 2001? On March 19 ${ }^{\text {th }}$, 2001 the Bank of Japan announced its quantitative easing policy. The announcement had three key features (Ugai, 2007): (1) the Bank of Japan would no longer target an interest rate, but instead would target the excess reserves of commercial banks held at the Bank of Japan - the Bank's so-called current account balance. (2) Quantitative easing would be explicitly state-dependent. It would continue until deflation ended. (3) The Bank of Japan would purchase long-term government bonds.

The effects of this policy are clearly visible in figure 4(a), which shows a rapid acceleration in monetary base growth after March 2001. Despite this massive increase in liquidity provision, broad money growth was only slightly positive (figure 4(b)). And in the year following March 2001, professional forecasters' inflation expectations fell and the real exchange rate depreciated only slightly. The real effects of quantitative easing appear to ultimately have been small (Ugai,

\footnotetext{
${ }^{32}$ To get a better sense of how Abenomics changed the inflation expectations of professional forecasters, one can look at inflation expectations in October 2012 and October 2013. Since the consumption tax increase was passed in June 2012, the difference between the earlier and later forecasts provides an estimate of the effect of Abe's new policies on inflation expectations. This measure of inflation expectations rose at all time horizons.
} 
2007). Krugman (1998, 2000) and Eggertsson and Woodford (2003) argue that this is exactly what one would expect of a policy that merely temporarily increases monetary aggregates without changing expectations about inflation or future nominal rates. For quantitative easing to be effective it must either lower nominal interest rates or raise expected inflation or both. In general, this means it must be expected to persist even after the economy exits the zero lower bound. By contrast, if quantitative easing is expected to be temporary, then it will likely have little or no effect on expected future real interest rates and the broad money supply; consumers will simply substitute cash for deposits while banks hold excess reserves.

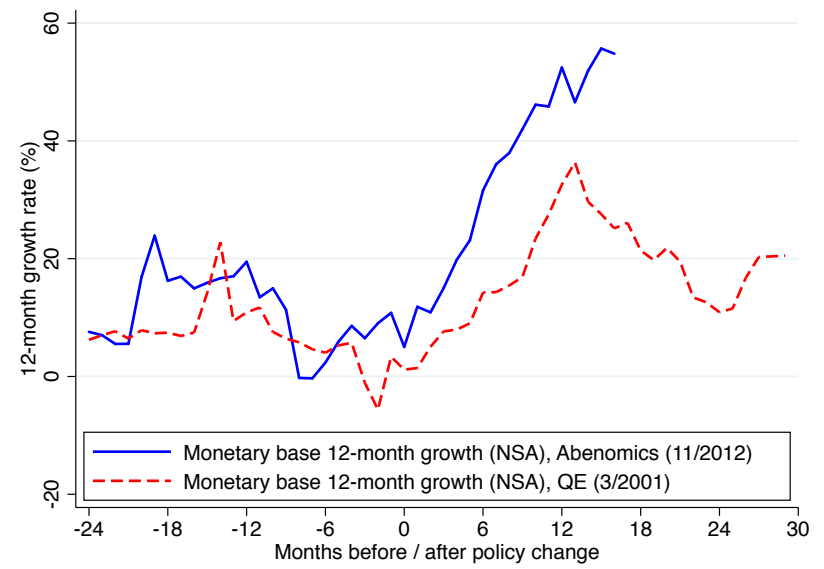

(a) Monetary base

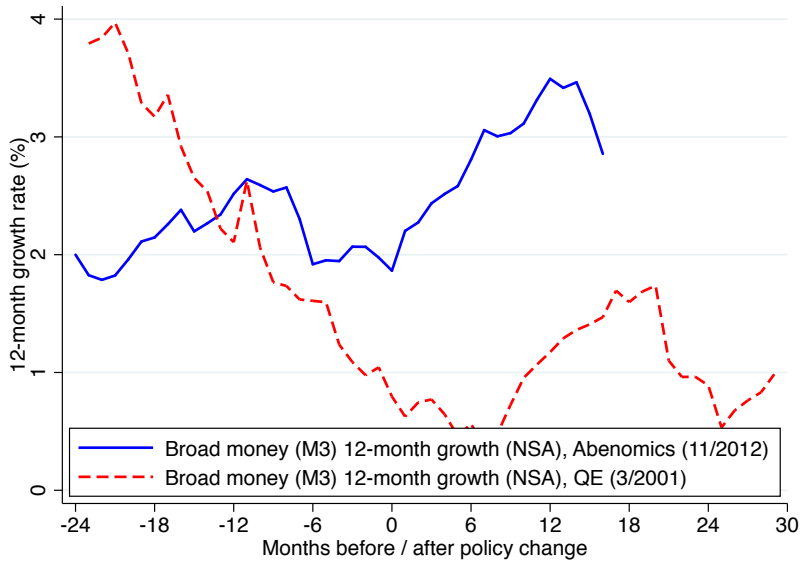

(b) Broad money (M3)

Figure 4 - Comparison of money growth during quantitative easing (QE) and Abenomics. Month 0 is March 2001 for quantitative easing and November 2012 for Abenomics. Source: See data appendix.

This appears to be what happened in the early 2000s. Quantitative easing was indeed temporary. In early 2006 the Bank of Japan mopped up most excess reserves (see Blinder, 2010, figure 8); later that year it raised the uncollateralized call rate to 0.25 percent. Yearover-year from 2005 to 2006, the monetary base fell 13 percent.

Figure 4 shows that Abenomics is different. The monetary base has grown more, but the most striking difference is in the behavior of the broad money supply which has grown much more rapidly during Abenomics. This is exactly what one would expect from a more credible monetary policy change. If, unlike in 2001, people now expect lower future real interest rates, the resulting increase in credit demand will also lead to money creation in the banking system. 
Thus the increase in the broad money supply. Even after a recent slowdown, the 12-month growth rate of broad money is now (3/2014) at its highest level since 1999. Taken together, figure 4 is a striking confirmation of model-based predictions. Exactly as predicted by Krugman (1998) and Eggertsson and Woodford (2003), a credible commitment to future expansion is having effects that temporary changes in the monetary base did not.

3.4 Output Ending deflation and increasing inflation expectations are intermediate goals. The ultimate target of Japan's new monetary policy is higher output. Here we document the turnaround of Japanese output in 2013. We then turn to the harder task of determining what part of recent Japanese growth is due to Abenomics and to monetary policy in particular.

Figure 5(a) shows quarterly GDP growth at an annual rate in Japan since 2007. Performance in 2013 was notably better than that at the end of 2012. Whereas quarter-on-quarter growth was negative in the second and third quarters of 2012, output grew during each quarter of 2013, and particularly so in the first half of the year. Fourth quarter over fourth quarter, the Japanese economy grew 2.6 percent in 2013; year-on-year it grew 1.5 percent.

However, the trend is negative: since the first quarter of 2013, growth has declined each quarter. The principal problem was net exports. Figure 5(b) shows that the contribution of exports to real GDP growth fell from 2.4 percentage points (at an annual rate) in the first quarter of 2013 to 0.2 percentage points in the final quarter of the year. At the same time, the contribution of imports fell from -0.7 percentage points to -2.4 percentage points. Put differently, had the contribution of net exports been the same in the fourth quarter as it was in the first, annualized fourth quarter growth would have been 4.6 percent rather than 0.7 percent. We will return to the puzzling behavior of net exports below.

Figure 5(c) provides a different way of seeing recent performance. It plots average annual GDP growth as well as the contributions of major components in 2013. For comparison, we also show average growth rates for two subsamples: the lost decades excluding the 2008 recession (1995-2007 33 ) and the 2008 recession and recovery (2008-2012). 2013 growth has been strong

\footnotetext{
${ }^{33}$ We start this comparison in 1995, since official national accounts data for the level of GDP become available in 1994.
} 
relative to these prior periods.

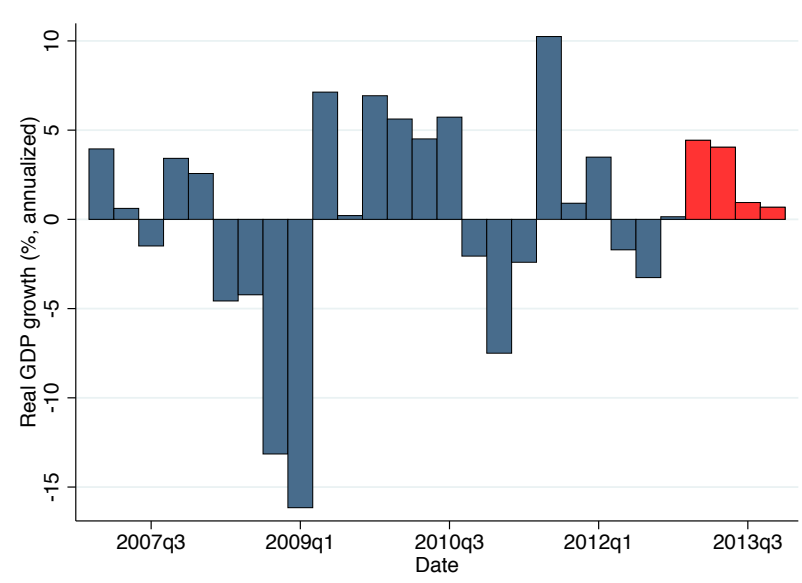

(a) Quarterly growth

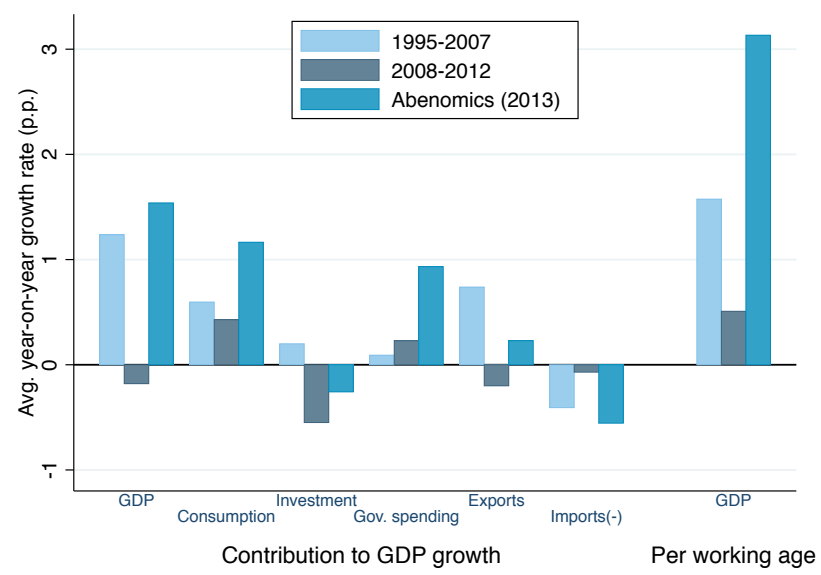

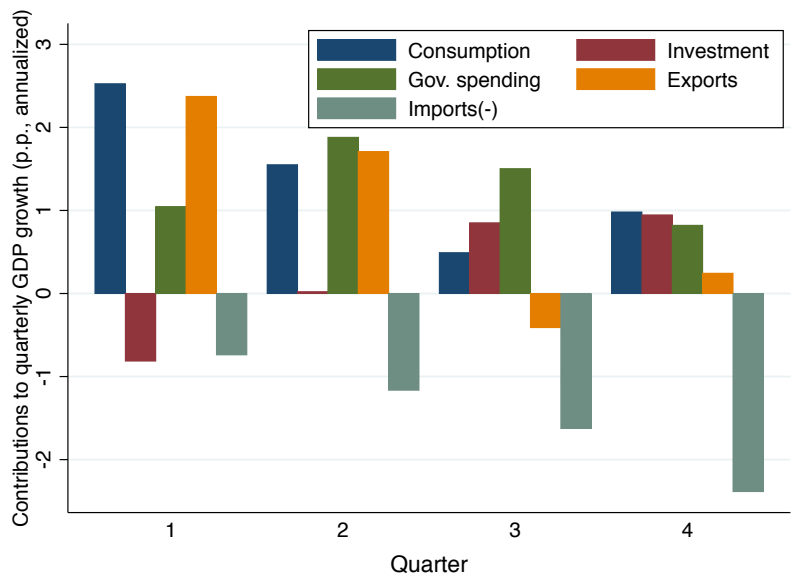

(b) Contributions to growth in 2013

(c) Contributions to growth

Figure 5 - Panel (a) shows annualized quarter-on-quarter GDP growth since 2007. Quarters since Abenomics began are marked in red. Panel (b) shows contributions to GDP growth by component for each quarter during 2013. Panel (c) provides a comparison of contributions to GDP by component during Abenomics (2012-2013), the lost decade excluding the Great Recession (1994-2007), and the Great Recession (2007-2012). Contributions are calculated as in Japan's national accounts. Panel (c) also displays working-age adjusted GDP growth. Source: see data appendix.

As we noted in section 2, when making historical (and international) comparisons it is important to adjust for Japan's changing demographics. The right-most bars in figure 5(c) show growth rates of output per person age 15 to 64 . Since the 15 to 64 year old population has been shrinking since 1995, this raises all growth rates. Population decline has, however, been particularly rapid since 2006, so this adjustment makes performance under Abenomics look more impressive: 2013 growth per working-age person was 3.1 percent, compared to 1.6 
percent from 1995 to 2007 and 0.4 percent from 2008 to 2012.

Output growth in 2013 is almost entirely accounted for by consumption, which contributed 1.2 percentage points, and government spending, which contributed 0.9 percentage points. Residential investment added another 0.3 percentage points. Non-residential investment, the change in inventories, and net exports subtracted a total of 0.8 percentage points from growth.

3.5 Forecasts Without a counterfactual, it is difficult to say how much of 2013 growth was due to Abenomics. We need to know what output would have been without Abenomics to know the effect of Abenomics. As an estimate of this counterfactual, we first look to forecasts from Consensus Economics made in late 2012, before Abe's policies were fully known.

What complicates our analysis is that news of the 2012 recession arrived almost simultaneously with Abe's first policy speeches. The first news of actual contraction came on November $12^{\text {th }}, 2012$, when preliminary GDP data showed that the economy contracted in the third quarter of 2012 at a 3.5 percent annual rate. ${ }^{34}$ This news came just days before Abe's "unlimited easing" speech on November $15^{\text {th }}$.

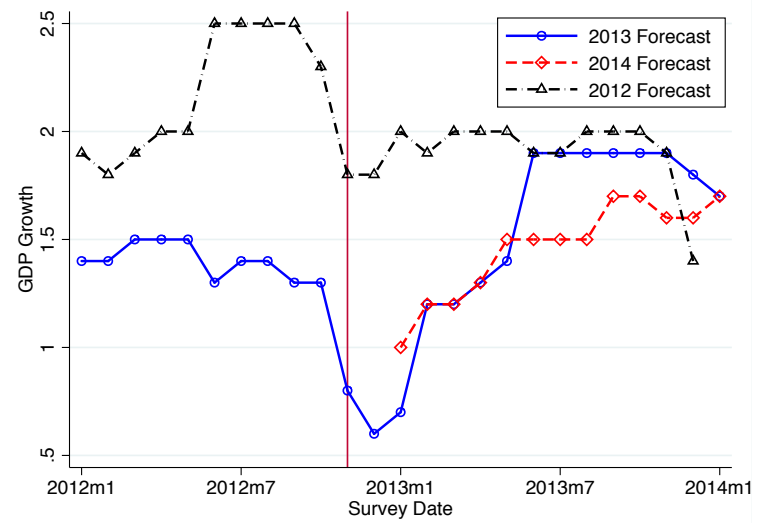

(a) GDP growth

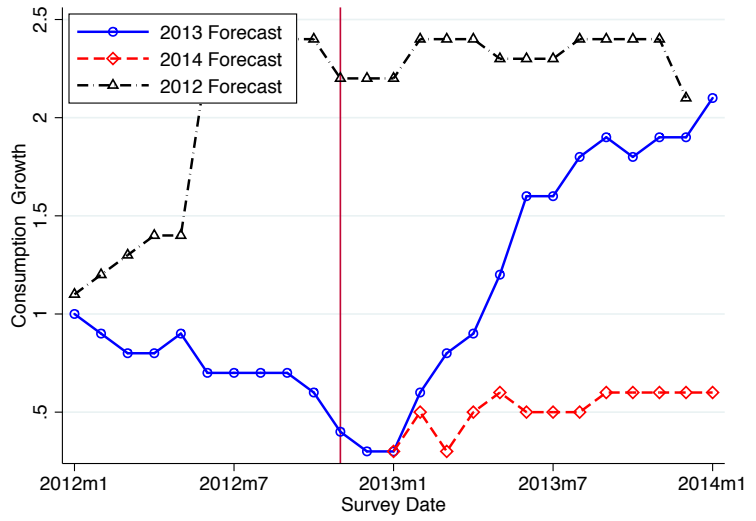

(b) Consumption growth

Figure 6 - 2012, 2013 and 2014 forecasts by survey date for GDP growth (panel a), and consumption growth (panel b). The vertical line is the first announcement of Abenomics, November 2012.

Forecasters interpreted bad news about growth in 2012 to also be bad news about growth in 2013. The GDP growth forecast for 2013 was revised down from 1.3 percent in October 2012 to 0.8 percent in November 2012. This is shown in figure 6, where we plot the evolution of

\footnotetext{
${ }^{34}$ See http://www.esri.cao.go.jp/jp/sna/data/data_list/sokuhou/files/2012/qe123/pdf/jikei_1.pdf.
} 
Consensus forecasts for GDP and consumption by survey date. Even in November the depth of the 2012 recession was not fully appreciated. On November $28^{\text {th }}$, data for October retail sales showed a larger than predicted 1.2 percent decline. ${ }^{35}$ While the 2012 growth forecast in figure 6(a) did not decline in December, this reflects single-digit rounding error in the mean forecast. The unrounded 2012 mean growth forecast fell from 1.84 percent in November to 1.80 in December. Forecasters read this as a negative signal for future growth: the 2013 growth forecast deteriorated from 0.8 percent in November 2012 to 0.6 percent in December. Given that so much was already known about actual 2012 GDP at this time, it is unsurprising that 2013 forecasts moved more than 2012 forecasts.

Thus it is not obvious what forecasts provide the best counterfactual. Forecasts made in early fall 2012, before Abe announced his polices, suffer from mistaken optimism about growth in 2013. This means these forecasts are an over optimistic counterfactual. By contrast, later forecasts, in December 2012, more accurately reflect the 2012 recession's effect on the 2013 growth outlook but were made when then-candidate Abe was widely expected to win the election and after some of Abe's initial economic policy announcements. In particular, by December 2012, Abe had forcefully called for more expansionary monetary policy. To the extent that these announcements had a positive effect on the December Consensus forecasts, we will underestimate the effect of Abenomics.

Evidence that the December forecasts include some positive announcement effects comes from out-of-sample statistical forecasts. In table 3 we tabulate 2013 (year-on-year) growth forecasts from autoregressive and vector-autoregressive (VAR) models estimated with data through the fourth quarter of 2012. Columns 2 and 3 report the forecasts from an autoregressive model of quarterly GDP growth. These two columns differ in that column 2 estimates the model based on final data releases, whereas column 3 estimates the model based on the data available to professional forecasters' in December 2012. Columns 4 and 5 conduct the same exercise using a VAR with quarterly GDP growth, gdp deflator growth, and changes in the ten-year

\footnotetext{
${ }^{35}$ Bloomberg
} 
bond yield. ${ }^{36}$ We estimate all models with one to four lags (AIC and BIC criteria consistently favor one lag) starting in 1996 when the zero lower bound began to bind.

The consistent result is that 2013 growth is forecast to be lower than thought by professional forecasters in December 2012. This is true even when one uses the data available to forecasters at the time (columns 3 and 5). This suggests that professional forecasts include positive expectations about the effects of Abenomics. ${ }^{37}$ While the standard errors for the VAR forecasts are large (as they are for the Consensus forecasts), ${ }^{38}$ we are encouraged that the forecasts do better in 2012 than in 2013. Estimating the models through 2011 and forecasting 2012 growth yields estimates ranging from 1.46 percent to 2.31 percent; actual GDP growth was 1.45 percent.

Table 3 - 2013 Growth forecasts from autoregressive models

\begin{tabular}{cccccc}
\hline \hline \multirow{2}{*}{$\operatorname{Lags}(=\mathrm{p})$} & \multicolumn{2}{c}{$\mathrm{AR}(\mathrm{p})$} & & \multicolumn{2}{c}{$\operatorname{VAR}(\mathrm{p})$} \\
\cline { 2 - 3 } \cline { 5 - 6 } & $\begin{array}{c}\text { Final release } \\
\text { data }\end{array}$ & Forecast data & & $\begin{array}{c}\text { Final release } \\
\text { data }\end{array}$ & Forecast data \\
\hline 1 & -0.09 & -0.16 & & -0.25 & -0.05 \\
2 & 0.02 & -0.06 & & -0.11 & -0.17 \\
3 & 0.06 & -0.04 & & 0.43 & 0.38 \\
4 & 0.06 & -0.25 & & 0.38 & 0.11 \\
\hline
\end{tabular}

Notes: 2013 year-on-year growth forecasts in percent based on autoregressive and vector-autoregressive models. Column 1 shows the number of autoregressive lags. Columns 2 and 3 show forecasts from autoregressive models of GDP growth estimated from 1996Q1 to 2012Q4. Columns 4 and 5 display forecasts from vector-autoregressive models of GDP growth, GDP deflator growth, and changes in the 10-year bond yield estimated from 1996Q1 to 2012Q4. Column 2 and 4 use actual data, whereas columns 3 and 5 use the data available to professional forecasters in December 2012 (except for the GDP deflator, which comes from the 2/2013 GDP release-see the text).

\footnotetext{
${ }^{36}$ Columns three and five use data from the GDP release on December $10^{t h}, 2012$. This release had no data for the fourth quarter of 2012. For this quarter, we use the Consensus Economics forecast for GDP. Consensus Economics does not forecast the GDP deflator, so for this variable we use the value from the February $14^{t h}$, 2013 GDP release.

${ }^{37}$ Some of this difference could also be due to expected intertemporal substitution in advance of the April 2014 consumption tax increase. In fact, as we discuss below, the evidence suggests that the consumption tax increase explains relatively little of 2013 growth.

${ }^{38}$ Since the $R^{2}$ of these regressions are small, the conditional variance (squared standard error) of our forecasts are only slightly below the unconditional variance of output growth. From 1996 to 2012 output growth had an unconditional variance of 0.000529 or a standard deviation of 2.3 percent. However, this sample also includes episodes such as the Asian financial crisis, the Great Recession, and the 2011 Japanese earthquake. Conditional on not observing similar global events in 2013, our estimate for the range of plausible 2013 growth rates should be smaller. For example, excluding these events and their recoveries (1997-8,2008-11) from the sample yields a standard deviation of 0.9 percent. Thus conditional, on not observing these large shocks, our estimated effects - 0.9 percent to 1.8 percent - range from one to two (conditional) standard deviations of output growth.
} 
The VAR and forecast-based counterfactuals imply that Abenomics raised 2013 growth by roughly a percentage point. Actual year-over-year growth was 1.5 percent compared to the 0.6 percent forecast by Consensus Economics in December 2012. This implies a 0.9 percentage point effect of Abenomics on growth. As we argued above, we believe this estimate is conservative. For instance, our most pessimistic VAR forecast suggests that 2013 growth would have been -0.25 percent. That would imply a much larger 1.75 percentage point contribution to 2013 growth from Abenomics. Further confirming that Abenomics added at least a percentage point to growth is an estimate from the IMF. In October 2013, the IMF argued that the entire package of policies would add 1.3 percentage points to 2013 growth (International Monetary Fund (2013c), p. 49). The IMF did not describe how it obtained this estimate, and it may now (in early 2014) be out of date. Still, we are encouraged that it is close to our figures.

Figure 6 shows that the primary improvement in output relative to the December 2012 forecast was in consumption. The December 2012 Consensus forecast was for 0.3 percent consumption growth; in fact — as indicated by the rapid improvement in the forecast over 2013 consumption grew 1.9 percent. This difference alone accounts for a percentage point of output growth. While not provided by Consensus Economics, a comparison to the OECD Economic Outlook forecast suggests that government consumption growth exceeded expectations due to Abe's fiscal stimulus. At the same time, business investment (not shown) underperformed relative to expectations. The December 2012 forecast was for 0.4 percent growth; actual growth was -1.6 percent. This underperformance is mysterious since one would expect stimulative monetary policy to have large effects on business investment. In our view, the most likely explanation is that forecasters were simply over optimistic in December $2012^{39}$ and/or already incorporated positive announcement effects from Abenomics.

3.6 Which Arrow? While a conservative read of the evidence suggests that Abenomics increased 2013 output by one percent, it is less clear whether this should be ascribed to the monetary, fiscal, or structural arrow. In our view there are at least two compelling reasons

\footnotetext{
${ }^{39}$ For instance, if low 2012 growth reduced firm cash flows and these are needed to finance investment because of credit frictions (Fazzari, Hubbard, and Petersen, 1988), then continuous downward revisions in the 2012 output forecast could trigger downward revisions in the 2013 investment forecast.
} 
to believe that the third arrow has not yet been a major contributor. First, there has been little if any structural reform passed, let alone implemented. Thus the third arrow would have to work through anticipation effects, but it is not clear what consumers and firms anticipate. Second, the improvement in growth and growth forecasts has coincided with a rise in prices and inflation expectations (figure 3). If anticipation of structural reforms were the dominant driver of real effects, we should observe falling prices and inflation forecasts.

We therefore focus on disentangling the first and second arrows: how much of Abenomics' boost to 2013 growth was due to monetary policy and how much to fiscal policy? This question is as challenging as it is important. Fiscal policy was first discussed in December 2012 and was formally announced in January 2013, ${ }^{40}$ the same month that the Bank of Japan announced its two percent inflation target. Thus it is difficult to use timing to separate the effects of the two policies. Instead, we focus on movements in different components of GDP.

To have any hope of disentangling the effects of these two policies, we need to say something about the size of Abe's fiscal stimulus. We compare the current IMF estimate of the cyclicallyadjusted primary budget balance to the IMF forecast before Abe's fiscal stimulus was revealed. In October 2012, the IMF forecast that Japan's cyclically adjusted primary budget deficit as a share of potential GDP would be 7.5 percent (International Monetary Fund, 2012). In October 2013, the IMF estimated it would be 8.5 percent (International Monetary Fund, 2013b). This implies an unexpected fiscal stimulus equal to 1.0 percent of GDP in 2013. ${ }^{41}$

A case can be made, therefore, that there is little growth for monetary policy to explain in 2013. Suppose that Abenomics as a whole added one percentage point to 2013 output growth. If there was one percent of GDP worth of fiscal stimulus, a multiplier of one would explain all of this excess growth. Nonetheless, the behavior of consumption in 2013 strongly suggests that monetary policy also contributed to growth.

Recall that 2013 consumption growth exceeded forecasts by 1.6 percentage points, enough to contribute an entire percentage point to output growth. Consumption's strength is difficult

\footnotetext{
${ }^{40}$ See SCMP and Bloomberg.

${ }^{41}$ See also International Monetary Fund (2013a), p. 1. To be precise, this is 1.0 percent of potential GDP. But since the IMF believes that actual Japanese GDP is close to potential, the difference is small.
} 
to explain by fiscal policy. Unlike the U.S. stimulus in 2009 and 2010 (the American Recovery and Reinvestment Act), little, if any, of Abe's stimulus consisted of transfer payments or lower taxes for households. ${ }^{42}$ So there was no direct mechanism through which a larger budget deficit translated into higher consumption.

Evidence that the second arrow is not solely responsible for strong 2013 consumption growth comes from the time-series pattern of consumption and government spending in figure $5(\mathrm{~b})$. Across quarters in 2013, there is a slight negative correlation between consumption growth and government spending growth. If government spending were raising private consumption through an old Keynesian multiplier effect, one would expect to see the opposite pattern. ${ }^{43}$

In addition to evidence against fiscal stimulus explaining consumption growth, there is evidence for monetary policy explaining this growth. Consider the spending patterns documented in Japan's Family Income and Expenditure Survey. Among so-called 'worker households,' households with a member employed, real disposable income fell 1.3 percent between 2012 and 2013. This fits with the more rapid increase in prices than in wages documented in section 3.2 and with the lack of any substantial new government transfer payments. At the same time as incomes fell, real consumption expenditures rose 0.9 percent, exactly as one would expect if a lower real interest rate was inducing households to spend sooner rather than later. Furthermore, from 2012 to 2013, the value of new loans taken rose nine percent.

The composition of consumer spending also suggests a role for monetary policy. Among worker households, the largest positive contribution to consumer spending was in the transportation category, especially spending on private vehicles. A similar pattern is visible in the aggregate national accounts data. Consumption spending on durable goods rose 15.7 percent from the fourth quarter of 2012 to the fourth quarter of 2013.

Along with consumer durables, residential investment is likely to be one of the components

\footnotetext{
${ }^{42}$ Forty-eight percent of Abe's supplementary budget was public investment, 32 percent was private investment subsidies, and 14 percent was transfers to local governments. The remaining seven percent was medical and educational spending. (These figures are based on Abe's supplementary budget released in January 2013. See budget.)

${ }^{43}$ Government spending could raise consumption through intertemporal substitution by raising marginal production costs and inflation expectations and thus lowering real interest rates. However, evidence from Wieland (2014) and Dupor and Li (2013) suggests that this mechanism is unlikely to be quantitatively important.
} 
of GDP most responsive to the real interest rate (Bernanke and Gertler, 1995). Here too, one sees large effects. Fourth quarter over fourth quarter, real residential investment grew 10.4 percent. This is particularly remarkable given that Japan's declining population presumably reduces demand for new housing.

Some of the increase in durables purchases and private residential investment may be driven by the consumption tax increase. In April 2014, Japan's consumption tax will rise from five percent to eight percent. The consumption tax increase is a large part of why short-term real interest rates were lower than long-term real interest rates in 2013 (figure 2(c)). It applies to houses as well consumption goods, so its effects are also likely to show up in residential investment. Furthermore, a similar consumption tax increase occurred in April 1997, and it appears to have pulled forward durables purchases. ${ }^{44}$ We doubt, however, that the tax increase is a major contributor to the increase in household spending in 2013. Most obviously, it has been expected since 2012, yet forecasters in December 2012 did not expect significant consumption growth in 2013. Therefore it seems implausible that the consumption tax increase can explain why year-over-year consumption growth exceeded December 2012 forecasts by 1.6 percentage points. Furthermore, consumption growth was particularly strong in the first two quarters of 2013 (figure 5(b)), but intertemporal substitution in advance of the tax increase ought to have had larger effects later in the year.

That we do not see such effects at the end of 2013 does not imply a lack of any intertemporal substitution. Rather it appears likely that the consumption tax mostly boosted consumption in the first quarter of 2014, thus not affecting our estimates of Abenomics' contribution to 2013 growth. The December 2013 Consensus Economics forecast was for consumption to grow 6 percent at an annual rate in the first quarter of 2014. In our view, it is more plausible that the consumption tax increase explains some part of 2013 residential investment growth than that it explains much of 2013 consumption growth. But even here, there is a strong hint that monetary policy mattered: from December 2012 to June 2013, the percent of borrowers choosing fixed

\footnotetext{
${ }^{44}$ Fourth quarter over fourth quarter, in 1996 real GDP rose 3.4 percent, consumer durables 12.0 percent, and residential investment 17.4 percent.
} 
rather than variable rate mortgages increased by almost 10 percentage points. ${ }^{45}$

Overall we believe there are plausible reasons to attribute much of the increase in consumption to monetary policy. If we simply assign all of the consumption increase relative to the forecast counterfactual to the monetary arrow, then Japan's new monetary policy raised 2013 output growth by roughly a percentage point. This might be an overestimate, insofar as some excess consumption growth came from other causes and was spent on imports. But it might also be an underestimate, insofar as it ignores the likely small but positive effects of monetary policy on residential investment and net exports.

Take one percentage point as our estimate of the contribution of monetary policy to 2013 growth. Together with fiscal stimulus of one percent of GDP and a multiplier of one, this would imply a total Abenomics effect of two percentage points. ${ }^{46}$ That is much larger than the 0.9 percentage point difference between actual growth and the Consensus Economics forecast in December 2012. But, as we noted above, this is a conservative counterfactual. If instead we use the most pessimistic forecast from the statistical models in table $3,-0.25$ percent, then Abenomics raised GDP growth by 1.75 percentage points, very close to the above calculation. In short, while one can make a case that monetary policy added little to 2013 growth, one can also argue that it added roughly a percentage point to GDP. This large confidence interval reflects the difficulty of disentangling simultaneous monetary and fiscal changes. Nevertheless, we find the evidence in favor of some positive effects of monetary policy to be compelling.

3.7 Discussion The above analysis implies that the effects of Japan's new monetary policy in 2013 were modest relative to the output gap. An important reason why the effects were not larger is the behavior of net exports. Despite the 20 percent depreciation of the yen in spring 2013, real net exports deteriorated over the year (figure 5(b)). Of course, that nominal net exports fell is unsurprising. Whether a currency depreciation raises nominal net exports depends on the Marshall-Lerner condition. Assuming that net exports are initially zero, the sum of import and export elasticities must exceed one in order for depreciation to raise nominal

\footnotetext{
${ }^{45}$ See Wall Street Journal.

${ }^{46}$ Auerbach and Gorodnichenko (2014) provide estimates of the government spending multiplier in Japan. Their estimates suggest large uncertainty about its current value.
} 
net exports. This condition is unlikely to be satisfied immediately, but is generally assumed to hold in the long-run. Initially there is little response of quantities, so price effects dominate and the trade balance deteriorates. But long-run elasticities are larger, so eventually quantities adjust and nominal net exports rise above their pre-depreciation value. This is the so-called J-curve (Magee, 1973; Bahmani-Oskooee and Ratha, 2004). Japan is still on the downward slope. Nominal net exports fell from minus 2.4 percent of GDP in the first quarter of 2013 to minus 3.7 percent of GDP in the fourth quarter of 2013.

In the real national accounts data, separate price deflators are used for each component of real GDP, including imports. So the price effects that have driven down Japan's nominal trade balance are taken out. Yen depreciation cannot explain why real net exports have subtracted from Japanese real GDP growth in 2013. Quite the opposite. As long as the elasticities of export and import volumes with respect to the real exchange rate are positive, a real depreciation should lead to some increase in export volumes and some decrease in import volumes.

In fact, year-over-year in 2013, export volumes (real exports) rose only 1.6 percent while import volumes rose 3.4 percent. Part of the explanation is that Japanese trade quantities appear to be quite inelastic with respect to yen movements. Japanese exports are overwhelmingly manufactures. In 2013, 73 percent of goods exports were in the categories of "manufactured goods," "machinery," "electrical machinery," and "transport equipment" (e.g. motor vehicles). These are sectors in which so-called pricing to market is likely. Exporters of manufactures are likely to set prices in foreign currency. These prices will be set for a variety of competitive reasons (e.g. to maintain market share) and will thus be relatively unresponsive to short-run changes in the yen's value. ${ }^{47}$ An older literature suggests that such pricing to market is more prevalent among Japanese exporters than it is among other countries' exporters (Dominguez, 1999; Gagnon and Knetter, 1995).

Consider one of Japan's largest exports: automobiles. Gagnon and Knetter (1995) (table 6) find that between 1978 and 1983, when the real value of the yen fell 39 percent against the dollar, the real retail price of a Honda Civic fell only 7 percent. Casual observation suggests

\footnotetext{
${ }^{47}$ There is a large literature on pricing to market. See Krugman (1987) and Atkeson and Burstein (2008).
} 
a similar phenomena today. Japanese cars sold in the U.S. are not 25 percent cheaper now than they were in 2012. Such pricing to market can explain why Japanese exports have not risen more. The number of Japanese cars exported, for instance, rose only 1.3 percent between December 2012 and December 2013.

Short-run elasticities may if anything be smaller for imports. Hooper, Johnson, and Marquez (2000) estimate that the short-run elasticity of Japanese imports with respect to the exchange rate is only -0.1. This estimate is based on historical data, but it is unlikely that recent changes have improved matters. In 2013, fossil fuels accounted for 34 percent of Japan's imports, equivalent to 5.7 percent of Japanese GDP. By contrast, in 2004, energy imports were only two percent of GDP. The change has been driven by the rise in the world price of oil and the 2011 tsunami. Prior to the tsunami, Japan produced roughly a quarter of its electricity from nuclear power. All nuclear reactors are now shut down, with fossil fuel imports substituted. Unfortunately for the trade balance, demand for imports - including fossil fuelsis quite inelastic. From December 2012 to December 2013, for instance, the quantity of oil imported rose 0.2 percent despite a 19 percent increase in the yen price of oil.

Aside from net exports, the effects of a weaker yen on real GDP are ambiguous. On the one hand, as documented in section 3.2, a weaker yen is a major reason why deflation ended in 2013. By raising actual inflation, yen weakness likely contributed to higher expected inflation and thus lower real interest rates. On the other hand, a weaker currency has direct negative effects on aggregate demand. More resources spent on imported goods mean fewer resources spent on domestic goods.

Thus, at least in Japan, currency depreciations appear to be a less effective short-run tool to jump-start an economy at the zero lower bound than originally anticipated. ${ }^{48}$ If the yen's current level proves persistent, however, it is likely that firms and consumers will change their behavior in ways that significantly lower imports and raise exports. Thus as long as yen weakness persists, it is reasonable to expect net exports to contribute to medium-run growth.

\footnotetext{
${ }^{48}$ For instance, McCallum (2000) and Svensson (2003) argue for currency depreciations to jump-start an economy at the zero lower bound, along with other measures such as price level targeting.
} 


\section{Medium-Run to Long-Run Outlook}

The previous section discussed the behavior of Japanese output and inflation in 2013. We argued that Abenomics as a whole likely added between 0.9 and 1.8 percentage points to 2013 growth, with strong, though circumstantial, evidence that monetary policy explains part of this gain. But proponents of Abenomics hope for more than one good year. Presumably the ultimate goal is to close Japan's output gap.

There are two distinct questions here. First, does Abenomics, and the monetary policy regime change in particular, pass a cost-benefit test? Do expected benefits, even if small, exceed costs? To that our answer is a likely yes. A different question is whether Japan's monetary policy is likely to have large output effects, perhaps large enough to close the large (and, as we shall see, possibly growing) output gap of 4.5 to 10 percent that we found in section 2.2. To that, our answer is that it is too soon to tell, but that there is of yet little evidence of effects this large.

We look at four sources of evidence on the medium to long-run effects of Abenomics: professional forecasts, the stock market, a comparison with Franklin Roosevelt's regime change, and Keynesian models. Unfortunately, each of these sources of evidence has problems, and they do not paint a consistent picture. In particular, current data and professional forecasts are inconsistent with the larger effects suggested by the analogy to the U.S. in 1933 and new Keynesian models.

It is worth emphasizing again that we take Abenomics' effect on inflation expectations as given. Inflation expectations have not (yet) risen to two percent (section 3). As we discuss further in section 5, if Japan's new inflation target becomes more credible, its positive effects will likely be larger.

4.1 Forecasts We first consider an obvious source: professional forecasts. In particular, we examine long-run forecasts from Consensus Economics. Figure 7(a) shows that between October 2012 and October 2013, professional forecasters not only raised their level forecasts for GDP, they also raised their long-run growth forecast from 0.9 percent to 1.1 percent. Output in 2022 
is predicted to be 3.1 percent above the pre-Abenomics forecast. Importantly, in October 2012, Japan had already legislated the 2014 and 2015 consumption tax increases, so the forecast change from October 2012 to October 2013 measures only the effects of Abe's new policies.

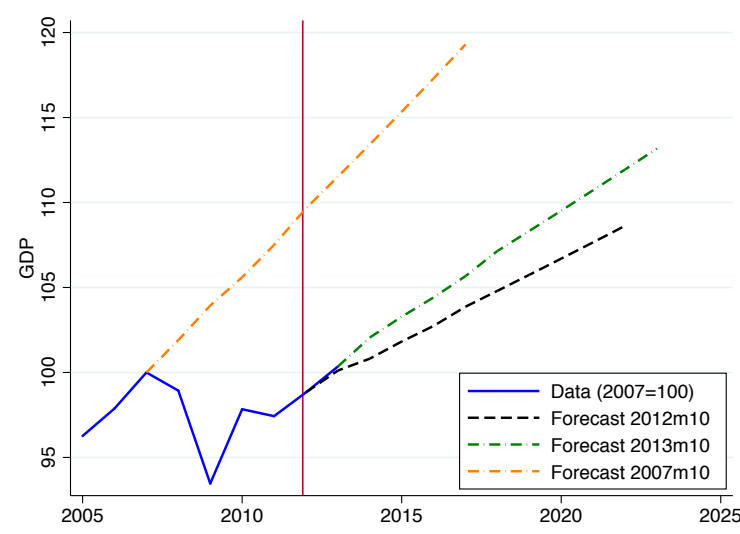

(a) GDP

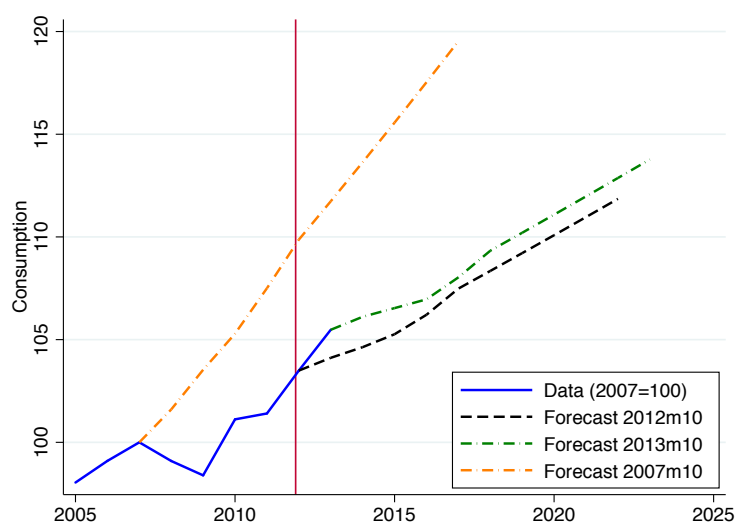

(b) Consumption

Figure 7 - Actual and forecast output and consumption. Forecasts are from Consensus Economics. Abenomics begins at vertical red line (2012).

Whether this forecast revision is good or bad news depends on one's perspective. It suggests a greater than three percent output gain in perpetuity. That is a large gain for any economic policy, particularly one with few obvious costs. On the other hand, these forecasts suggest little prospect of closing Japan's output gap. As a benchmark, we plot forecasts made in late 2007. In section 2.2 we argued that this provides a reasonable measure of the output gap. With this metric, output was 10 percent below potential in 2012. As of late 2012, this gap was projected to grow to 13 percent in 2017. While Abenomics is projected to raise long-run growth, current forecasts still show this gap widening to 11 percent in 2017. Put differently, forecasters do not expect Abenomics to close the gap with their 2007 view of Japanese economic prospects. If one had hoped that Japan's monetary regime change would eliminate Japan's demand side problems, this is disappointing news. ${ }^{49}$

The forecasts for consumption, non-residential investment (not shown), and industrial production (not shown) have similar implications. A one percent level gain is projected for con-

\footnotetext{
${ }^{49}$ Similar implications obtain from the Okun's law calculation of the output gap discussed in section 2.2. As of October 2013, the IMF forecasts that Japanese unemployment will be above 4.2 percent through 2018 (the end of the forecast horizon), implying a persistent 10 percent output gap (International Monetary Fund, 2013c).
} 
sumption, but that is not large enough to close the gap with the late 2007 projection. Consumption is forecast to grow less than output, presumably because forecasters expect a weaker yen to raise real net exports. Business investment in 2012 is more than 20 percent below the 2007 projection, and while Abenomics has led to upward forecast revisions, the change is too small to close this gap.

The forecast revisions we document here appear to be consistent with those of the general public. We examine the output expectations of individuals in the Bank of Japan opinion survey and firms in the Tankan business survey. ${ }^{50}$ Respondents to the Bank of Japan survey are pessimistic both before and after Abenomics. Pre-Abenomics, in September 2012, only 5.3 percent of respondents expected their income to rise over the next year, and 45.8 percent expected it to fall. In December 2013, 8.1 of respondents expected their income to rise, and 37.8 percent expected it to fall. So there is improvement. But since 80.9 percent of respondents in December 2013 expect prices to go up (either slightly or substantially), at least 72.8 percent of the polled population expect their real income to fall. By comparison, only 47 percent of respondents to the August 2013 U.S. Michigan consumer survey expect their real income to fall over the next year.

In the December 2013 Tankan survey, we examine whether firms describe business conditions as favorable or unfavorable, and whether firms say there is excess demand or excess supply for products and services. Net favorability ratings are now positive for the first time since the financial crisis. They are at their early-2007 level. But unsurprisingly, the current figures are some distance away from the very positive levels of the late 1980s. Responses to the excess supply question show that in 2013, instances of excess supply fell and those of excess demand rose. On net, excess supply still exceeds excess demand, but on this question responses have improved over their early 2007 levels.

These three sources of forecasts suggest cautious optimism. But at least so far, there are not signals of a dramatic break with the growth rates of the 1990s and 2000s. Of course, a limitation

\footnotetext{
${ }^{50}$ The Tankan survey polls a sample of 10,000 private enterprises with more than $¥ 20$ million in capital for quantitative and qualitative data.
} 
of this evidence is that it is difficult to know what part of Abenomics is driving forecast revisions. Upward revisions could reflect forecasters' belief that growth-enhancing structural reforms will take place. Or perhaps forecasters think that monetary policy will increase growth, even in the long-run. The fact that long-run inflation forecasts have risen certainly points to an important role for monetary policy, since structural reforms would presumably lower expected future prices. But we cannot rule out the possibility that the real side is (in the long-run) primarily determined by structural reforms while the nominal side is primarily determined by monetary policy.

Even as an indicator of the effects of Abenomics as a whole, these forecasts are not definitive. Economic forecasters have no crystal ball, and their past experience could be a misleading guide to the effects of a large-scale policy change. Previous work has shown that forecasters may be slow in updating to news (Coibion and Gorodnichenko, 2012). In appendix tables 5 and 6 we show that short- and long-run professional forecast revisions have historically been reasonable in the sense that they were unbiased. In other words, when GDP growth forecasts are revised from 0.5 percent to 1 percent, our best guess is that actual GDP growth will be 1 percent. This makes us sufficiently confident to present the forecast data here, but it does not establish that the forecasts will be good guides to Japan's future.

4.2 Stock market The small changes in forecasts of professionals and households may seem surprising given Japan's dramatic stock market boom. Between October 2012 and December 2013, the Nikkei 225 rose by 77 percent and the broader Topix index by 70 percent. Does this not suggest much larger real effects of Abenomics than implied by professional forecasts? To answer this question, we investigate how well stock prices forecast dividend growth.

To provide intuition for our exercise, we use the Gordon growth formula: when dividends $D$ grow at a constant rate $g$ and are discounted at a constant rate $r$, then the stock price is given by

$$
P=\frac{D}{r-g} .
$$

Thus prices should be proportional to dividends, holding $r$ and $g$ constant. 
In 2013, stock prices rose much faster than dividends. The MSCI Japan index, which has a long history of dividend data, has risen by 76.9 percent from October 2012 to December 2013 but nominal net dividends only rose by 9.1 percent since the third quarter of 2012. This suggests that either $r$ has fallen or $g$ has risen. But only an increase in growth rates would imply large real output effects. If discount rates $(r)$ fall, for instance, because investors become less risk averse or irrationally exuberant, then stock prices may not forecast real growth. ${ }^{51}$

One should keep in mind the limits of this exercise: the stock market, at best, forecasts dividend growth and not necessarily GDP growth. These series differ notably: dividends are much more volatile than GDP. Since 1980 the standard deviation of annual dividend growth (22.3 percent) is nine times that of GDP growth (2.5 percent). For example, in 2009 real GDP fell by 5.5 percent while dividends declined by 36.2 percent. The overall correlation between year-on-year GDP growth and dividend growth is quite low-only 0.14 since 1980. Thus, to the extent that the stock market is a poor forecaster of dividend growth, it is likely an even worse forecaster of GDP growth.

We follow Campbell and Shiller (1988) to determine how well the stock market has historically forecasted dividend growth in Japan. ${ }^{52}$ We define the (ex-post) discount rate $R_{t+1}$ as the value that makes current prices equal to discounted future prices plus dividends, $P_{t} \equiv \frac{P_{t+1}+D_{t+1}}{R_{t+1}}$. This implies that the discount rate is identical to the ex-post return. Log-linearizing this equation and solving forward for $h$ periods yields the Campbell-Shiller decomposition

$$
d_{t}-p_{t}=\sum_{j=0}^{h-1} \rho^{j} r_{t+j+1}-\sum_{j=0}^{h-1} \rho^{j} \Delta d_{t+j+1}+\rho^{h}\left(d_{t+h}-p_{t+h}\right) .
$$

Here $d_{t}-p_{t}$ is the $\log$ dividend-price ratio, $r_{t+j+1}$ are future log discount rates, $\Delta d_{t+j+1}$ is $\log$ dividend growth, and $\rho=\frac{1}{1+\exp \{\overline{d-p}\}}<1$ is a constant. For large $h$, and in the absence of bubbles, the last term will be close to zero. Thus, as a matter of accounting, low dividend-price ratios must be followed by either lower future discount rates (i.e., lower future returns) or higher

\footnotetext{
${ }^{51}$ Note that our use of the term "discount rates" encompasses both rational and behavioral elements as in Cochrane (2011). It should thus be thought of as a residual: any price movements we cannot explain with dividend levels or dividend growth will necessarily show up in discount rates.

${ }^{52}$ The first study we are aware of that tests for predictability of returns using the dividend-price ratio in Japan is Campbell and Hamao (1992).
} 
dividend growth. One can determine the importance of each component with the regressions,

$$
\begin{gathered}
\sum_{j=0}^{h-1} \rho^{j} r_{t+j+1}=a_{r}^{h}+b_{r}^{h}\left(d_{t}-p_{t}\right)+\varepsilon_{r, t}^{h} \\
\sum_{j=0}^{h-1} \rho^{j} \Delta d_{t+j+1}=a_{d}^{h}+b_{d}^{h}\left(d_{t}-p_{t}\right)+\varepsilon_{d, t}^{h} .
\end{gathered}
$$

These regressions answer the following question: Given that stock prices have risen faster than dividends in 2013, should we expect higher growth (higher $g$ in (1)) or lower discount rates in the future (lower $r$ in (1))? In other words, we are asking how well the stock market has historically forecasted growth. Note that for large enough $h$ (and absent bubbles), we should find that $b_{r}^{h}-b_{d}^{h}=1$. Further, the size of the coefficients determines the relative importance of discount rates versus dividend growth: If $b_{r}^{h} \approx 1$ then the dividend-price ratio forecasts discount rates (returns); if $b_{d}^{h}=-1$ then the dividend-price ratio forecasts future dividend growth. In their seminal work, Campbell and Shiller (1988) show that in the U.S., the dividend-price ratio almost exclusively forecasts discount rates and not dividend growth, i.e., $b_{r}^{h} \approx 1$ and $b_{d}^{h} \approx 0$.

Table 4 tabulates the coefficients $b_{r}^{h}$ and $b_{d}^{h}$ at horizons of 10, 15, and 20 years for gross and net returns. Like Campbell and Shiller (1988), we find that the dividend-price ratio strongly forecasts discount rates (returns), with $b_{r}^{h} \approx 1$. By contrast, estimates of $b_{d}^{h}$ are always close to zero and typically insignificant. If anything, the positive estimates of $b_{d}^{h}$ imply that high prices relative to dividends forecast lower future dividend growth. What does this mean? If $b_{d}^{h}=0$, then prices have historically reverted to a level consistent with dividends. Since dividends rose by approximately 9.1 percent in 2013, our best (long-run) forecast for future prices is that they will fall until they are 9.1 percent above those in November 2012. Thus, this exercise suggests caution in interpreting high stock prices (relative to dividends) as an implicit forecast of future dividend growth, even leaving aside the issues of linking dividend growth to GDP growth.

The stock market, at least unconditionally, gives no reason to expect future rapid growth in Japan. It is more likely that Japan will see falling stock prices than higher dividend growth. Or so the history suggests. To argue that the recent behavior of the stock market forecasts future growth, one needs to argue that this robust historical relationship does not hold today. 
Table 4 - Campbell-Shiller decomposition

\begin{tabular}{|c|c|c|c|c|c|c|}
\hline & \multicolumn{2}{|c|}{$h=10$ years } & \multicolumn{2}{|c|}{$h=15$ years } & \multicolumn{2}{|c|}{$h=20$ years } \\
\hline & $b_{r}^{h}$ & $b_{d}^{h}$ & $b_{r}^{h}$ & $b_{d}^{h}$ & $b_{r}^{h}$ & $b_{d}^{h}$ \\
\hline \multirow[t]{2}{*}{ Net Returns } & $0.97^{* *}$ & 0.03 & $1.23^{* *}$ & 0.08 & $1.13^{* *}$ & -0.03 \\
\hline & $(0.17)$ & $(0.16)$ & $(0.10)$ & $(0.09)$ & $(0.10)$ & $(0.05)$ \\
\hline \multirow[t]{2}{*}{ Gross Returns } & $0.95^{* *}$ & 0.07 & $1.19^{* *}$ & $0.13^{*}$ & $1.10^{* *}$ & 0.04 \\
\hline & $(0.16)$ & $(0.12)$ & $(0.11)$ & $(0.06)$ & $(0.10)$ & $(0.04)$ \\
\hline $\mathrm{N}$ & 133 & 133 & 113 & 113 & 93 & 93 \\
\hline
\end{tabular}

Notes: $b_{r}^{h}$ is the slope estimate of a regression of future realized returns, $\sum_{j=0}^{h-1} \rho^{j} r_{t+j+1}$, on the $\log$ dividendprice ratio $d_{t}-p_{t} . b_{d}^{h}$ is the slope estimate of a regression of future realized dividend growth, $\sum_{j=0}^{h-1} \rho^{j} \Delta d_{t+j+1}$, on the $\log$ dividend-price ratio $d_{t}-p_{t}$. The "net returns" row shows results for dividends net of taxes. The "gross returns" row shows results for gross dividends. $\rho=0.9874$ based on historical mean of dividend-price ratio. Newey-West standard errors are in parentheses (bandwidth $=h$ ). ${ }^{+} \mathrm{p}<0.10,{ }^{*} \mathrm{p}<0.05,{ }^{* *} \mathrm{p}<0.010$.

4.3 The Roosevelt analogy Given uncertain predictions from professional forecasts and the stock market, it is natural to turn to history as a guide to the prospects for Japan's monetary regime change. The analogy most often discussed is to Franklin Roosevelt's monetary policy regime change in spring 1933. This is far from the only possible analogy: for instance, one might fruitfully compare current Japanese policies to disinflation efforts in the U.S. and Europe in the early 1980s and to other countries' efforts to reflate in the 1930s. But given its prominence, we focus on the analogy to the U.S. in 1933.

The U.S. recovery after Franklin Roosevelt's inauguration in March 1933 is widely interpreted as evidence for the effectiveness of monetary policy regime changes - with direct implications for Japan (Temin and Wigmore, 1990; Eggertsson, 2008, Romer, 2013). ${ }^{53}$ And it is not only outside observers who have found the 1933 analogy useful. In a speech on December $25^{\text {th }}$, 2013, the Bank of Japan governor, Haruhiko Kuroda, argued that the U.S. economy's response to Roosevelt's actions shows that monetary policy can quickly raise inflation expectations (Kuroda, 2013). In the rest of this subsection we explore the extent to which this comparison is warranted: does 1933 indeed have lessons for Japan today?

Two obvious similarities have motivated comparisons. First, in 1933 in the U.S., as in Japan in 2012, the economy was suffering from deflation, the output gap was large, and monetary

\footnotetext{
${ }^{53}$ Also see this op-ed by Barry Eichengreen, http://english.caixin.com/2013-02-18/100491854.html?p2.
} 
policy was constrained by the zero lower bound. Second, Franklin Roosevelt, like Shinzo Abe, attempted a monetary policy regime change. He combined actions and words to convince the public that deflation would be replaced by moderate inflation. Of course the scale of the economic problems that confronted each leader was quite different. Roosevelt's inauguration followed three years of continuous large declines in output and prices. In 1932 alone, real GDP fell 13 percent and the CPI fell 10 percent. By contrast, over 14 years, from 1998 to 2012, the cumulative decline in the Japanese CPI was 4 percent.

Figure 8 shows the path of industrial production before and after Roosevelt and Abe took office. It makes clear why the Roosevelt example inspires optimism about Abenomics. In the four months following Roosevelt's inauguration, seasonally adjusted industrial production rose 57 percent. This initial expansion persisted: real GDP growth from 1934 through 1936 averaged 11 percent per year. Many economists have argued that this growth was primarily explained by the effects of Roosevelt's monetary policy on inflation and output expectations (Temin and Wigmore (1990), Romer (1992), Eggertsson (2008)).

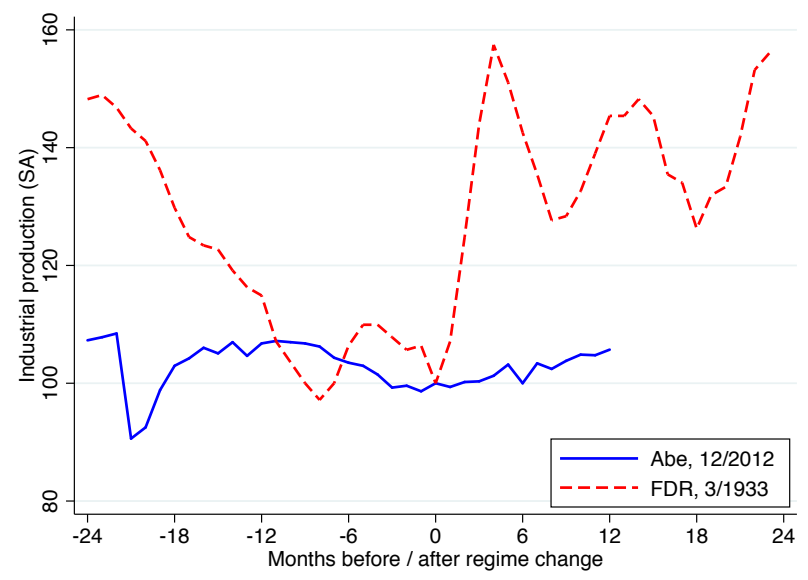

Figure 8 - Industrial production in the U.S. and Japan after Franklin Roosevelt took office in March 1933 and Shinzo Abe took office in December 2012. Industrial production is indexed to be 100 in the month that each leader took office. Source: See data appendix.

The lesson usually drawn from this episode is thus that regime changes can have large, sustained effects on output. It suggests that Japan's new monetary policy could have large output effects. But it also raises a puzzle: why did Roosevelt's actions have large, immediate effects in a way that Abe's policies have not? One answer is that Roosevelt's policy change 
was much larger. In appendix B, we provide a detailed comparison of the change in the real interest rate in Japan now with that in the U.S. between 1932 and 1934. Using inflation swaps as a measure of expected inflation, ex ante ten-year real interest rates fell 1.1 percentage points between October 2012 and March 2014 in Japan. As detailed in appendix B, real interest rates fell by two to four percentage points in the U.S. between 1932 and 1934.

This exercise suggests that the change in the real interest rate in the U.S. in 1933 was between two and four times as large as that in Japan in 2013. Therefore all else equal, one might expect the effects of Abenomics to be only a quarter to one half as large as those of Roosevelt's actions. But this only resolves part of the puzzle. Abenomics has achieved far less than half or even a quarter of U.S. growth after 1933. The optimistic view is that this puzzle will be resolved by future rapid growth in Japan; perhaps the difference between Japan now and the U.S. in 1933 is simply in the lags with which a monetary regime change affects the economy. We are more inclined towards the pessimistic view that 2013 data reflect fundamental differences between the current situation in Japan and that in the U.S. in 1933.

4.4 Keynesian models Like history, models are a natural place to turn for evidence on the effects of a new macro policy. In particular, since financial markets allow us to precisely measure the effect of Abenomics on the real interest rate, we combine this measure with a model-implied estimate of the effect of a change in the real interest rate on output.

We first use the baseline new Keynesian model from Woodford (2003, Ch. 4). It consists of an Euler equation, a new Keynesian Phillips curve, and an interest-rate rule. It implies the conventional IS relationship

$$
\hat{y}_{t}=-\sigma E_{t} \sum_{s=0}^{\infty} r_{t+s}+\hat{y}_{\infty},
$$

where $\hat{y}_{t}$ is the deviation of output from steady-state, $r_{t+s}$ is the ex-ante one-year real interest rate from $t+s$ to $t+s+1$, and $\sigma$ is the intertemporal elasticity of substitution. In this model, the (peak) change in output from reducing the annualized ten-year real rate by $r$ is $\frac{d Y}{d r}=-10 \sigma$. Since typical calibrations set $\sigma$ between 0.5 and 1 (e.g., Eggertsson and Woodford (2003); Christiano, Eichenbaum, and Evans, 2005; Smets and Wouters, 2007), the 1.1 percentage point 
decline in the ten-year real interest rate $^{54}$ should raise output by 5.5 to 11 percent. Since there are no sources of persistence in this model, the output effect should be immediate.

As a second example, consider the Smets and Wouters (2007) model. This is a medium-scale new Keynesian model that incorporates, among other features, capital, habits, sticky-wages, price- and wage-indexation, and interest-rate smoothing. We take the estimated parameters in Smets and Wouters (2007) as given and conduct the following experiment. First, we subject the model to a discount factor shock such that the zero lower bound binds for eight quartersthe maximum duration for which a unique equilibrium exists in the model. Next we add a one-standard-deviation monetary policy shock and calculate the difference in outcomes with and without the monetary shock. We are particularly interested in two numbers: the change in ten-year real interest rates, $d r$, and the maximum change in output due to the monetary shock, $d Y$. We then calculate the peak interest-rate semi-elasticity of output, $\frac{d Y}{d r}$. The result is -7.0 after five quarters. Based on the 1.1 percentage point decline in the ten-year real interest rate, this model predicts an increase in output of $7.0 \times 1.1=7.7$ percent after five quarters.

Unlike in the baseline new Keynesian model, the effects of a real interest rate change in the Smets-Wouters model are not literally immediate. But they happen more quickly than is consistent with Japanese data. Most of the decline in Japanese real interest rates had occurred by late spring 2013, but output does not look as if it will be 6 or 7 percent higher in summer 2014. Thus conventionally calibrated new Keynesian models suggest much larger - or at least faster - gains than are currently apparent in the data or in professional forecasts.

Like the new Keynesian IS curve, an old Keynesian IS curve suggests large effects of a change in the real interest rate. But since (some) old Keynesian models are purely backward looking, they can do a better job of matching an initially small output gain in 2013. Consider the old Keynesian IS curve suggested by Ball (1999): $y_{t}=\lambda y_{t-1}-r_{t-1}$, where $y_{t}$ is the natural $\log$ of output in year $t$. Ball (1999) calibrates $\lambda$ to be $0.8 .^{55}$ Assuming that the reduction in

\footnotetext{
${ }^{54}$ This is the decline in figure 2(c) between October 2012 and March 2014. Most of this decline in the real interest rate occurred in the first half of 2013; between October 2012 and May 2013 the real interest fell 0.9 percentage points.

${ }^{55}$ Ball (2006) argues that $\lambda$ is 0.6 in Japan. For comparison with the new Keynesian models calibrated with U.S. data, we use $\lambda$ equal to 0.8 .
} 
ten-year bond yields is spread out equally over time, this implies an output gain of 4.9 percent after ten years. ${ }^{56}$ Because the IS curve is purely backward looking, the dynamics are slow. Output gains in the first year after the real interest rate change are only equal to the change in the real interest rate. Thus this model fits with positive but small output gains from monetary policy in 2013. It suggests that the gains from monetary policy will be more visible in 2014 .

While old and new Keynesian models disagree about the speed of adjustment to a monetary regime shift, they both suggest that the medium-run effects of monetary policy are larger than professional forecasts imply. Furthermore, throughout this analysis we have assumed that the monetary regime shift will remain imperfectly credible and thus will only lower future real interest rates by 1.1 percentage points. Assuming that the policy becomes more credible over time would imply even larger effects. In short, Keynesian models imply large real effects from the first arrow of Abenomics. That we do not (yet) observe such rapid growth suggests three possibilities. First, that (unobserved) negative shocks have been reducing Japanese growth. Such shocks would, however, need to be as large as the 2008 financial crisis to depress growth from 6 to 7 percent implied by the model to the 1.5 percent we observe in the data. In our view, more plausible candidates are that real-world dynamics are primarily backward-looking (as in old Keynesian models) or that these models overestimate the effect of monetary policy.

4.5 The Consumption Tax Increases We have primarily focussed on monetary policy, since it is the most radical element of Abenomics. But it is worthwhile comparing the future effects of Japan's expansionary monetary policy with those of the consumption tax increases. As discussed in section 3, fiscal policy has become contractionary due to the sales tax increase in April 2014 (from 5 to 8 percent) and that scheduled for October 2015 (from 8 to 10 percent). Here we confine ourselves to an examination of how these legislated tax increases affect long-run forecasts. $^{57}$

The original tax bill was passed on June $26^{\text {th }}$ 2012. We compare long-term forecasts for 2014 and 2015 made in April 2012 and October 2012. 2014 growth forecasts were revised down by 0.5

\footnotetext{
${ }^{56}$ The effect in year $t$ is given by $y_{t}=1-0.8^{t} / 1-0.8 \times 1.1$ for $t$ less than or equal 10 .

${ }^{57}$ Of course, just as with monetary policy, one could explore other sources of evidence on the effects of the consumption tax increases.
} 
percentage points and 2015 forecasts by 0.1 percentage points. This may be an upper bound on the negative effects of the consumption tax increase. From April 2012 to October 2012, growth forecasts for all years were generally revised down by 0.1 to 0.2 percentage points, suggesting that during these six months other bad news was revealed. This forecast-based estimate of the consumption taxes' effect can be compared to model-based estimates from the IMF that imply a 1.0 percent cumulative contraction. ${ }^{58}$ The forecast revisions after the consumption tax increase are much smaller than those that occurred after Abe's new policies were revealed even if we focus solely on the years 2014 and 2015. As discussed above, and as shown in figure 7, between October 2012 and October 2013, forecasters revised up their estimate of 2014 growth by one percentage point and 2015 growth by 0.2 percentage points.

It is in some sense a semantic matter whether one wishes to consider the consumption tax increases to be part of Abenomics. They are not new policies. But Abe adopted them, and they are often considered an integral part of his 'second arrow.' What our discussion suggests is that even taking account of these tax increases, Abenomics will likely have net positive effects on output.

4.6 Discussion The preceding pages may appear needlessly complicated: why not simply look to a model or to forecasters for insight into Japan's future prospects? Our discussion of several sources has, however, been deliberate. We do not believe that any single source is a reliable guide. Here we return to the two motivating questions of this section: (1) will Abenomics' future benefits exceed costs? And (2) will Abenomics close Japan's output gap?

We start with the latter question. In section 2.2, we estimated the 2013 output gap in Japan to be 4.5 to 10 percent. It appears unlikely that Abenomics will close a gap this large; current professional forecasts suggest the gap will actually widen. The historical behavior of the Japanese stock market suggests that lower stock prices are more likely to lie in Japan's future than are higher profits and dividends. And both the 1933 analogy and new Keynesian models have difficulty explaining slow growth in Japan in 2013, suggesting that these two sources may

\footnotetext{
${ }^{58}$ Kang, Keen, and Pradhan (2011) show that a VAT increase of 1 percent of GDP reduces GDP by 0.4 percent in the IMF's GIMF model for Japan (their figure 4). We combine this with the estimated budget impact of the consumption tax increase of 2.5 percent of GDP to obtain the 1.0 percent figure in the text.
} 
be poor guides to the future.

Of course, this conclusion is enormously uncertain. Professional forecasters could be wrong. Japan's economy may simply be responding more slowly than the U.S economy did in 1933 or new Keynesian models predict. Or perhaps very large negative shocks depressed the Japanese economy in 2013, and the large gains suggested by history and new Keynesian models will become visible in 2014.

To the first question, we have both a more certain and more positive answer: the benefits of Japan's new monetary policy, and Abenomics as a whole, appear almost certain to exceed the costs. In part, this is because all the data point to at least some positive output effect. But even if monetary policy has no effect on output, the real interest rate decline has benefits for Japan's fiscal situation. Here we perform an illustrative calculation that compares the effects of a change in the real interest rate with the effects of other policies on Japan's budget outlook.

We take 2013 net debt of 140 percent of GDP from the October 2013 World Economic Outlook and the following values from Doi, Hoshi, and Okimoto (2011): tax rates and social security contributions are 30 percent of GDP, general government expenditure (including social security benefits) are 39 percent of GDP, and annual real GDP growth is 1 percent. We further assume that the real interest rate on debt for the next ten years is initially 0.43 percent per year - the yield on ten-year government bonds minus the ten-year inflation swap rate in October 2012. We then compare the evolution of debt over the next ten years with and without Abe's fiscal and monetary policy. Abenomics' impact consists of raising expenditures temporarily by 1 percent of GDP in year one and 0.5 percent in year two, raising tax income permanently by 1.5 percent of GDP in year two and another 1 percent in year three, and lowering the real interest rate on debt by 1.1 percentage points per year. ${ }^{59}$ We make the conservative assumption that any future deficits must be financed with debt carrying the old 0.4 percent real interest rate.

In the baseline scenario without Abenomics, net debt rises to 220 percent of GDP after

\footnotetext{
${ }^{59}$ We implicitly assume that the government refinances all debt into ten-year bond yields. In practice, since most of the decline in real interest rates comes from a rise in expected inflation (which does not require refinancing to affect real debt levels), this assumption is likely not particularly important.
} 
ten years. With Abenomics net debt rises to 185.3 percent. Thus Abenomics has shaved 34.8 percentage points off the future debt burden. Most of the decline is accounted for by the consumption tax increase (21 percentage points) though the fall in real interest rates is a non-trivial second (14.2 percentage points). ${ }^{60}$ The temporary stimulus packages, on the other hand, play only a very small role over the ten-year horizon. Note that to be conservative, this simulation excludes any effects of Abenomics on real GDP. If Abenomics increases real GDP, it will further reduce the debt to GDP ratio. This effect would come both through a larger denominator and through the effect of higher tax revenue on the numerator.

In short, Abenomics has improved the fiscal outlook through both the tax hikes and the monetary arrow. If improving the fiscal outlook is a good thing in and of itself, then Abenomics, and more expansionary monetary policy in particular, looks like good policy, even if one believes output effects will be small or nonexistent.

Against the benefits of Japan's new monetary policy, one must tally the costs. To our mind, these are likely small. One might think that the most obvious cost is higher inflation. This is not necessarily true. Costs of higher price dispersion and deviations from the Friedman rule need to be balanced against the benefit of higher steady-state nominal interest rates, which allow the economy to avoid the zero lower bound. Coibion, Gorodnichenko, and Wieland (2012) suggest that in an economy like Japan's, the optimal inflation rate is more likely to be two percent than it is to be zero percent. ${ }^{61}$

Another possible concern is that higher inflation will at some point drive down nominal bond prices through the Fisher effect. Relative to a no-Abenomics baseline, this would have no adverse effects on the government budget (unless real interest rates rose with nominal interest rates). But it might cause problems for the banking sector, which holds large amounts of government debt on its balance sheet (Hoshi, 2013). As of early 2014, this scenario is entirely speculative. Abenomics has thus far driven up the price of government bonds, improving the position of banks who hold these bonds.

\footnotetext{
${ }^{60}$ Joseph Gagnon has also made the point that declining real interest rates have large fiscal benefits for Japan. See http://blogs.piie.com/realtime/?p=3624.

${ }^{61}$ Ball (2013) argues for even higher inflation targets.
} 
Another possible concern is how the Bank of Japan will eventually normalize monetary policy after expanding its balance sheet to an unprecedented size. In principle, the Bank of Japan should be able contain any inflationary pressures by paying interest rates on (the nowexpanded) excess reserves (Hall and Reis, 2013). By raising interest rates, however, it would suffer losses on its portfolio of long-run government bonds. As emphasized by Bernanke (2000, 2003), such losses need not be of any economic consequence. Whether a central bank transfers resources to the government or vice-versa ought to be irrelevant for macroeconomic policy. But in practice, the distinction between positive and negative transfers may be politically important, with required positive transfers to the central bank endangering central bank independence (Hall and Reis, 2013). Given the already close cooperation between the Bank of Japan and Abe's government, we doubt that such transfers would lead to large changes in Bank of Japan policy. Furthermore, as detailed by Bernanke (2003), the Japanese Ministry of Finance and the Bank of Japan could agree to an interest rate swap that would mostly eliminate the Bank of Japan's balance sheet risk. Thus we see little reason for this concern to have much influence on Japanese policy. Central bank solvency concerns could be more important in other countries, where unconventional expansionary monetary policy might not be endorsed by the government as a whole.

A common worry is also that unconventional monetary policy will lead financial institutions to "reach for yield," by taking on more risk than is optimal for the financial system as a while. This has been discussed more in the U.S. than in the Japanese context, but it is a risk of any policy that pushes down safe real interest rates, as Abenomics has. Chodorow-Reich (2014) shows that unconventional monetary policy also affects financial institutions through other channels, some of which are likely to reduce vulnerability to shocks. Both in theory and, at least in the U.S., in practice, it is not at all clear that the "reach for yield" effect dominates.

Overall, we see the evidence as strongly in favor of positive net benefits from Abenomics whether considered as an entire policy package or as monetary policy alone. This is the more remarkable since we have not considered the third arrow - structural reforms. Abe's structural reforms are as yet imprecisely specified, so we have left a detailed treatment to further work. 
But the right reforms could undoubtedly raise potential and actual GDP. ${ }^{62}$

\section{Credibility}

We have thus far taken the effects of Abenomics on inflation expectations as given. We have evaluated a policy that has not yet convinced markets or professional forecasters that the two percent target will be reached. Even the Japanese government appears to be of two minds about the credibility of this target: in December 2013, Takahiro Mitani, the head of the semi-autonomous Japanese Government Pension Investment Fund, said that he expects CPI inflation to remain between 0.1 and 1 percent. ${ }^{63}$

This raises two questions. First, why has the Bank of Japan been unable to make its target fully credible? Second, is there a way the Bank of Japan could make its target more credible?

Start with the first question. The Bank of Japan's lack of credibility is in some ways odd. Two percent inflation is not high by international standards. And in standard new Keynesian models if an inflation target is optimal then it is also a feasible (time-consistent) policy for a central bank that cannot commit to future actions (Woodford, 2003, Ch. 7). These points of reference suggest that the Bank of Japan ought to be able to raise inflation expectations to two percent (or more).

Despite this, there are two good reasons to doubt the Bank of Japan's commitment. First, the Bank of Japan now has a record of announcing that it will achieve higher inflation and failing to do so. In February 1999, it began its 'zero interest rate policy.' It emphasized that it would maintain this policy "until deflation concerns subside" (qtd. in Ito and Mishkin (2006), p. 145). In fact, it raised the interest rate to 0.25 percent in August 2000, a year in which the the price level fell 0.7 percent (Ito and Mishkin, 2006). Likewise, when the Bank of Japan began its quantitative easing program in March 2001, it said it would continue the policy until CPI inflation excluding fresh food was positive. In this case, it followed the letter of its commitment,

\footnotetext{
${ }^{62}$ Perhaps most obviously, women's labor force participation in Japan's lags behind that in the U.S. The 'activity rate' for women age 15 to 64 (number of women employed plus unemployed divided by the female population) was 65 percent in Japan in the third quarter of 2013 versus 67.2 percent in the U.S. Some of Abe's proposals, such as more funding for childcare, could help eliminate this gap.

${ }^{63}$ Bloomberg
} 
ending the policy in March 2006 after several months of positive inflation (Ugai, 2007). But prices quickly began falling again: in the twelve months from March 2006 to March 2007, the CPI excluding fresh food fell 0.3 percent.

Demographics and the structure of Japan's pension system compound this credibility problem. Japan's large retired population has benefited from deflation. In theory, Japanese pensions are indexed to CPI inflation. But in practice, when CPI inflation has been negative, this indexation has been incomplete or has occurred only with a long lag. ${ }^{64}$ Furthermore, the Japanese population holds over half its financial wealth in bank deposits and currency (compared to 13 percent in the U.S.). Inflation imposes losses for which (at the very least) those who are retired cannot be compensated for with labor market improvement. ${ }^{65}$

The combination of benefits to the retired population and this group's outsized political power leads Feldman, Berner, Caron, Mutkin, and Minack (2010) to argue that Japan "made a social decision to entrench deflation" (p. 3) in the 2000s. Regardless of whether one entirely agrees, the presence of a large constituency that benefits from deflation naturally leads to questions about the government's commitment to two percent inflation. There is at least a hint of evidence that forecasters fear that Japan's next government might be less committed to this target. After the Liberal Democratic party, led by Abe, won seats in the House of Councillors on July 21, 2013, both 5 and 10 year inflation swap rates rose, albeit only slightly.

Much of this discussion suggests that credibility is outside the control of the Bank of Japan: it cannot change Japan's demography or pension system. This implies that for the Bank of Japan to merely announce a different target would have little effect. For instance, while there are well-known advantages to a credible price level target (Eggertsson and Woodford, 2003), it is unclear why a price level target would be any more credible than Japan's current inflation target, and by extension, whether Japan would see large benefits from adopting it. By contrast, further actions by the Bank of Japan could well help to make the current two percent inflation target more credible. One lesson from the financial market response to monetary

\footnotetext{
${ }^{64}$ See Hosen (2010) and Ministry of Finance slides, p. 27. Incidentally, this lack of indexation is another reason why inflation might improve Japan's fiscal situation.

${ }^{65}$ Bank of Japan, p.2.
} 
announcements (section 3.1) is that for the Bank of Japan, actions speak louder than words. No doubt in part because it had not lived up to past commitments, merely committing to higher inflation, as it did in January 2013, had a much smaller effect on markets than the announcement of asset purchases ("Quantitative and Qualitative Monetary Easing") in April. This suggests that further large-scale asset purchases could be beneficial.

If the Bank of Japan does manage to convince the public of its two percent inflation target, this will likely further stimulate the economy. By raising current long-term inflation expectations from 1.3 percent to two percent, long-term real interest rates would decline a further 0.7 percentage points. A linear model suggests this would increase the effects of the policy by more than 50 percent. As an illustrative calculation of the long-run effects of full credibility, consider professional forecasts of output in 2022. Abenomics (excluding the consumption tax increases) led this forecast to be revised up by 3.1 percent (section 4.1). If this is entirely a monetary policy effect, then full credibility could leave 2022 output roughly 5 percent above its no Abenomics baseline. Although illustrative, this is likely an overestimate of what full credibility would achieve. The currently observed 3.1 percent upward forecast revision may reflect expectations of structural reforms, not only monetary policy effects. Still, this calculation shows that making the two percent inflation target credible could have large benefits and ought to be a high priority for the Japanese government.

\section{Conclusion and Outlook}

We have provided a preliminary evaluation of Abenomics and Japan's monetary regime change in particular. Our analysis suggests that Abenomics as a whole raised 2013 GDP growth by 0.9 to 1.8 percentage points, with monetary policy accounting for up to one percentage point of this gain. This suggests large net welfare gains from Abenomics. But there is as yet little evidence that the policy will close Japan's output gap, which we estimated to be 4.5 to 10 percent in 2013 (section 2.2). For instance, professional forecasts suggest an output gain from Abenomics (excluding the consumption tax increases) of 3.1 percent by 2022. Since the output gap implied by professional forecasts was projected to widen to 13 percent in 2017 absent 
Abenomics, this gain is far from enough to close the gap. Of course, future performance is highly uncertain, and it is quite possible that Abenomics may exceed (or underperform) our and professional forecasters' expectations. We therefore conclude with a brief discussion of what future data releases would point to larger effects of Abenomics.

In part the modest effects of Abenomics relative to the output gap reflect the imperfect credibility of the policy. Thus expected inflation is a crucial indicator. If our analysis is correct, future upward movements in inflation expectations - whether measured by inflation swaps or surveys of professional forecasters - will be accompanied both by higher actual growth and higher expectations of future growth. Concretely, as of January 2014, the Consensus forecasts for 2014 growth and 2015 growth are 1.7 and 1.2 percent. If inflation expectations rise, we expect the Japanese economy to beat these forecasts, perhaps significantly.

Sustained monetary stimulus likely depends on the outcome of future wage negotiations. Assuming the marginal propensity to consume out of profits is low, real consumption cannot grow indefinitely if CPI inflation continues to outstrip money wage growth. Quite simply, this would violate individual budget constraints. Furthermore, a two percent inflation target may not be politically sustainable if, in addition to lowering retirement incomes, inflation lowers the incomes of working Japanese.

In the short-run, the contractionary effects of fiscal policy are also an important unknown. With the consumption tax implemented in April 2014, there will be uneven growth: as of the December 2013 quarterly consensus forecasts, output is expected to grow at an annualized rate of 4.9 percent in the first quarter and -4.7 percent in the second quarter. If the Japanese economy can exceed these forecasts, and resume growth in the second half of 2014, this would be very good news for Abenomics. It would mean avoiding a repeat of the 1997 recession, which some have attributed to the 1997 consumption tax hike.

Perhaps the largest long-run unknown about Abenomics is the third arrow, structural reforms. No one yet knows what reforms will be enacted or what the effect of these reforms will be. If this arrow is to have large effects, we would expect to see it first in rising forecasts of real future growth and lower inflation expectations. If inflation expectations fall at the same 
time as growth forecasts rise, this would suggest that forecasters expect positive future supply shocks.

Developments in Japan should be of wide interest to macroeconomists. The outcome of Abenomics will determine whether Japan experiences another lost decade or resumes healthy growth. Abenomics' success may also influence policy in Europe and the U.S. As this was going to press, in April 2014, both the Federal Reserve and the European Central Bank were up against the zero lower bound, with inflation near one percent on both sides of the Atlantic. Thus far, neither the Federal Reserve nor the European Central Bank has considered a radical regime shift. If Abenomics succeeds, that may change.

\section{References}

Atkeson, Andrew and Ariel Burstein, "Pricing-to-Market, Trade Costs, and International Relative Prices," American Economic Review, 2008, 98 (5), 1998-2031.

Auerbach, Alan J and Yuriy Gorodnichenko, "Fiscal Multipliers in Japan," 2014.

Bahmani-Oskooee, Mohsen and Artatrana Ratha, "The J-Curve: A Literature Review," Applied Economics, 2004, 36 (13), 1377-1398.

Ball, Laurence, "Efficient Rules for Monetary Policy," International Finance, 1999, 2 (1), 63-83. _ , "The Case for Four Percent Inflation," Central Bank Review, 2013, 13 (2).

Ball, Laurence M, "Fiscal Remedies for Japan's Slump," in Takatoshi Ito and Andrew K. Rose, eds., Monetary Policy under Very Low Inflation in the Pacific Rim, NBER-EASE, Volume 15, University of Chicago Press, 2006, pp. 279-306.

_ , "Hysteresis in Unemployment: Old and New Evidence," 2009.

Bank of Japan, "Introduction of the 'Price Stability Target' and the 'Open-Ended Asset Purchasing Method'," 2013.

_ , "Introduction of the 'Quantitative and Qualitative Monetary Easing,," 2013.

Bernanke, Ben, "Japanese Monetary Policy: A Case of Self-Induced Paralysis?," in Ryoichi Mikitani and Adam Posen, eds., Japan's Financial Crisis and Its Parallels to U.S. Experience, Institute for International Economics, September 2000, pp. 149-166.

Bernanke, Ben S, "Some Thoughts on Monetary Policy in Japan," Technical Report, Federal Reserve Board 2003.

- and Mark Gertler, "Inside the Black Box: The Credit Channel of Monetary Policy," Journal of Economic Perspectives, 1995, 9 (4), 27-48.

Blanchard, Olivier, "Bubbles, Liquidity traps, and Monetary Policy: Comments on Jinushi et al, and on Bernanke," in Ryoichi Mikitani and Adam Posen, eds., Japan's Financial Crisis and Its Parallels to U.S. Experience, Institute for International Economics, September 2000, pp. 185-193.

Blinder, Alan S, "Quantitative Easing: Entrance and Exit Strategies," Federal Reserve Bank of St. Louis Review, 2010, 92 (November/December 2010).

Campbell, John Y and Robert J Shiller, "The Dividend-Price Ratio and Expectations of Future Dividends and Discount Factors," Review of Financial Studies, 1988, 1 (3), 195-228.

_ and Yasushi Hamao, "Predictable Stock Returns in the United States and Japan: A Study of Long-Term Capital Market Integration," Journal of Finance, 1992, 47 (1), 43-69. 
Cecchetti, Stephen G, "Prices During the Great Depression: Was the Deflation of 1930-1932 Really Unanticipated?," American Economic Review, 1992, 82 (1), 141-156.

Chodorow-Reich, Gabriel, "Effects of Unconventional Monetary Policy on Financial Institutions," in "Brookings Panel on Economic Activity Conference Draft" 2014.

Christiano, Lawrence J, Martin Eichenbaum, and Charles L Evans, "Nominal Rigidities and the Dynamic Effects of a Shock to Monetary Policy," Journal of Political Economy, 2005, $113(1), 1-45$.

Cochrane, John H, "Presidential Address: Discount Rates," Journal of Finance, 2011, 66 (4), 1047-1108.

Coibion, Olivier and Yuriy Gorodnichenko, "Information Rigidity and the Expectations Formation Process: A Simple Framework and New Facts," 2012.

_ and _ , "Is The Phillips Curve Alive and Well After All? Inflation Expectations and the Missing Disinflation," 2013.

_ , _, and Johannes Wieland, "The Optimal Inflation Rate in New Keynesian Models," Review of Economic Studies, 2012, 79 (4), 1371-1406.

Deardorff, Alan, "Trade Implications of the Trans-Pacific Partnership for Asean and Other Asian Countries," 2013. Research Seminar in International Economics, Discussion Paper No. 638.

Doi, Takero, Takeo Hoshi, and Tatsuyoshi Okimoto, "Japanese Government Debt and Sustainability of Fiscal Policy," Journal of the Japanese and International Economies, 2011, 25 (4), 414-433.

Dominguez, Kathryn, "The Role of the Yen," International Capital Flows, 1999, pp. 133-171.

Dupor, William and Rong Li, "The 2009 Recovery Act and the Expected Inflation Channel of Government Spending," 2013.

Eggertsson, Gauti B, "Great Expectations and the End of the Depression," American Economic Review, 2008, 98 (4), 1476-1516.

- and Michael Woodford, "The Zero Bound on Interest Rates and Optimal Monetary Policy," Brookings Papers on Economic Activity, 2003, (1), 139-233.

Eichengreen, Barry, "Japan Rising?," Milken Institute Review, October 2013, pp. 15-25.

Fazzari, Steven M, R Glenn Hubbard, and Bruce C Petersen, "Financing Constraints and Corporate Investment," Brookings Papers on Economic Activity, 1988, pp. 141-206.

Feldman, Robert Alan, Richard Berner, James Caron, Laurence Mutkin, and Gerard Minack, "Deflation: Will America and Europe Follow Japan?," 2010. Morgan Stanley MUFG Global Economics.

Gagnon, Joseph E and Michael M Knetter, "Markup Adjustment and Exchange Rate Fluctuations: Evidence from Panel Data on Automobile Exports," Journal of International Money and Finance, 1995, 14 (2), 289-310.

Hall, Robert E and Ricardo Reis, "Maintaining central-bank solvency under new-style central banking," Hoover Institution, Stanford University, and Columbia University, 2013.

Hamilton, James D, "Was the Deflation during the Great Depression Anticipated? Evidence from the Commodity Futures Market," American Economic Review, 1992, pp. 157-178.

Hooper, Peter, Karen Johnson, and Jaime Marquez, Trade Elasticities for the G-7 Countries number 87. In 'Princeton Studies in International Economics.', International Economics Section, Department of Economics, Princeton University, 2000.

Hosen, Mitsuo, "Japan's Public Pension: The Great Vulnerability to Deflation," 2010. Economic and Social Research Institute, Cabinet Office, Government of Japan, ESRI Discussion Paper No. 253.

Hoshi, Takeo, "Will Abenomics Restore Japan's Growth?," 2013.

_ and Anil Kashyap, "Why Did Japan Stop Growing?," NIRA Report, 2011. 
- and Takatoshi Ito, "Defying Gravity: How Long Will Japanese Government Bond Prices Remain High?," 2012.

International Monetary Fund, "Fiscal Monitor: Taking Stock, A Progress Report on Fiscal Adjustment," Technical Report, Washington: International Monetary Fund 2012.

_ , "Fiscal Monitor: Fiscal Adjustment in an Uncertain World," Technical Report, Washington: International Monetary Fund April 2013.

_ , "Fiscal Monitor: Taxing Times," Technical Report, Washington: International Monetary Fund October 2013.

_, "World Economic Outlook: Transitions and Tensions," Technical Report, Washington: International Monetary Fund 2013.

Ito, Takatoshi, The Japanese Economy, Vol. 10, MIT press, 1992.

_, "'Abenomics': Early Success and Prospects," Economy, Culture, and History: Japan Spotlight, September/October 2013, pp. 4-7.

- and Frederic S Mishkin, "Two Decades of Japanese Monetary Policy and the Deflation Problem," in Takatoshi Ito and Andrew K. Rose, eds., Monetary Policy under Very Low Inflation in the Pacific Rim, NBER-EASE, Volume 15, University of Chicago Press, 2006, pp. 131-202.

Jacobson, Margaret and Filippo Occhino, "Behind the Slowdown of Potential GDP," 2013. Federal Reserve Bank of Cleveland.

Kang, Kenneth, Michael Keen, and Mahmood Pradhan, Raising the Consumption Tax in Japan: Why, When, How?, International Monetary Fund, 2011.

Kato, Takao, "The End of Lifetime Employment in Japan?: Evidence from National Surveys and Field Research," Journal of the Japanese and International Economies, 2001, 15 (4), 489-514.

Kennedy, David M, Freedom from Fear: The American People in Depression and War, 19291945, Oxford University Press, 1999.

Krugman, Paul, "Pricing to Market when the Exchange Rate Changes," 1987.

_, "It's Baaack: Japan's Slump and the Return of the Liquidity Trap," Brookings Papers on Economic Activity, 1998, (2), 137-205.

_ , "Thinking about the Liquidity Trap," Journal of the Japanese and International Economies, 2000, 14 (4), 221-237.

_ , "PPP and Japanese Inflation Expectations," 2013.

Kuroda, Haruhiko, "Overcoming Deflation and After," 2013.

Kuttner, Kenneth N and Adam Simon Posen, "The Great Recession: Lessons for Macroeconomic Policy from Japan," Brookings Papers on Economic Activity, 2001, (2), 93-185.

Magee, Stephen P, "Currency Contracts, Pass-Through, and Devaluation," Brookings Papers on Economic Activity, 1973, pp. 303-325.

Mandel, Benjamin R. and Geoffrey Barnes, "Japanese Inflation Expectations, Revisited," 2013.

McCallum, Bennett T, "Theoretical Analysis Regarding a Zero Lower Bound on Nominal Interest Rates," 2000.

Olivei, Giovanni and Silvana Tenreyro, "Wage-Setting Patterns and Monetary Policy: International Evidence," Journal of Monetary Economics, 2010, 57 (7), 785-802.

Posen, Adam Simon, Restoring Japan's Economic Growth, Vol. 57, Peterson Institute, 1998.

Rogers, John H, Chiara Scotti, and Jonathan H Wright, "Evaluating Asset-Market Effects of Unconventional Monetary Policy: A Cross-Country Comparison," FRB International Finance Discussion Paper, 2014, (1101).

Romer, Christina, "It Takes a Regime Shift: Recent Developments in Japanese Monetary Policy Through the Lens of the Great Depression," 2013.

Romer, Christina D, "The Prewar Business Cycle Reconsidered: New Estimates of Gross Na- 
tional Product, 1869-1908," Journal of Political Economy, 1989, 977 (1), 1-37.

_ , "What Ended the Great Depression?," Journal of Economic History, 1992, 52 (04), 757-784.

_ , "Why Did Prices Rise in the 1930s?," Journal of Economic History, 1999, 59 (1), 167-199.

Romer, David H, Short-Run Fluctuations, University of California, 2012.

Schnell, Molly K and David E Weinstein, "Evaluating the Economic Response to Japan's Earthquake," 2012.

Smets, Frank and Rafael Wouters, "Shocks and Frictions in US Business Cycles: A Bayesian DSGE Approach," American Economic Review, 2007, 97 (3), 586-606.

Svensson, Lars E O, "Escaping from a Liquidity Trap and Deflation: The Foolproof Way and Others," 2003.

Temin, Peter and Barrie A Wigmore, "The End of One Big Deflation," Explorations in Economic History, 1990, 27 (4), 483-502.

Ueda, Kazuo, "The Response of Asset Prices to Monetary Policy under Abenomics," Asian Economic Policy Review, 2013, 8 (2), 252-269.

Ugai, Hiroshi, "Effects of the Quantitative Easing Policy: A Survey of Empirical Analyses," Monetary and Economic Studies-Bank of Japan, 2007, 25 (1), 1-47.

Wieland, Johannes F, "Are Negative Supply Shocks Expansionary at the Zero Lower Bound?," 2014. University of California-San Diego, Working Paper.

Woodford, Michael, Interest and Prices: Foundations of a Theory of Monetary Policy, Princeton University Press, 2003. 
APPENDIX (ONLINE ONLY) 


\section{A Forecast unbiasedness}

Table 5 - Bias of Quarterly Consensus Forecasts

\begin{tabular}{cccccc}
\hline \hline LHS & $y_{t}-y_{t \mid t-1}$ & $y_{t}-y_{t \mid t-2}$ & $y_{t}-y_{t \mid t-3}$ & $y_{t}-y_{t \mid t-4}$ & $y_{t}-y_{t \mid t-5}$ \\
RHS & $y_{t \mid t}-y_{t \mid t-1}$ & $y_{t \mid t-1}-y_{t \mid t-2}$ & $y_{t \mid t-2}-y_{t \mid t-3}$ & $y_{t \mid t-3}-y_{t \mid t-4}$ & $y_{t \mid t-4}-y_{t \mid t-5}$ \\
& & & & \\
\hline
\end{tabular}

Panel A: CPI

$\begin{array}{lccccc}\beta_{1} & 1.06^{* *} & 1.19^{* *} & 1.05^{* *} & 1.23^{* *} & 1.11^{* *} \\ \mathrm{~N} & (0.10) & (0.14) & (0.17) & (0.21) & (0.30) \\ R^{2} & 82 & 80 & 80 & 79 & 78 \\ & 0.521 & 0.462 & 0.285 & 0.284 & 0.143\end{array}$

Panel B: GDP

\begin{tabular}{lccccc}
\hline$\beta_{1}$ & $0.72^{+}$ & $1.27^{* *}$ & 0.19 & $0.68^{* *}$ & $0.81^{* *}$ \\
$\mathrm{~N}$ & $(0.36)$ & $(0.36)$ & $(0.36)$ & $(0.26)$ & $(0.22)$ \\
$R^{2}$ & 69 & 70 & 70 & 70 & 68 \\
& 0.144 & 0.138 & 0.004 & 0.091 & 0.089
\end{tabular}

Panel C: Consumption

\begin{tabular}{lccccc}
\hline$\beta_{1}$ & $0.82^{*}$ & 0.38 & $1.32^{* *}$ & $0.56^{+}$ & 0.14 \\
$\mathrm{~N}$ & $(0.35)$ & $(0.34)$ & $(0.49)$ & $(0.30)$ & $(0.26)$ \\
$R^{2}$ & 64 & 63 & 63 & 63 & 61 \\
& 0.161 & 0.016 & 0.196 & 0.062 & 0.003
\end{tabular}

Panel D: Industrial Production

\begin{tabular}{lccccc}
\hline$\beta_{1}$ & $1.23^{* *}$ & $1.31^{* *}$ & $1.38^{* *}$ & $1.59^{* *}$ & $1.53^{*}$ \\
$\mathrm{~N}$ & $(0.10)$ & $(0.17)$ & $(0.24)$ & $(0.30)$ & $(0.58)$ \\
$R^{2}$ & 81 & 79 & 80 & 79 & 77 \\
& 0.847 & 0.532 & 0.378 & 0.283 & 0.079
\end{tabular}

Note: Estimated coefficient $\beta_{1}$ from the regression $y_{t}-y_{t \mid t-l-1}=\beta_{0}+\beta_{1}\left(y_{t \mid t-l}-y_{t \mid t-l-1}\right)+\eta_{t} . y_{t \mid t-l}$ are forecasts for variable $y_{t}$ at date $t-l$. Data are from Consensus forecasts at quarterly frequency. Newey-West standard errors in parentheses. ${ }^{+} \mathrm{p}<0.10,{ }^{*} \mathrm{p}<0.05,{ }^{* *} \mathrm{p}<0.010$. 
Table 6 - Bias of Annual Consensus Forecasts

\begin{tabular}{|c|c|c|c|c|c|}
\hline $\begin{array}{l}\text { LHS } \\
\text { RHS }\end{array}$ & $\begin{array}{c}y_{t}-y_{t \mid t-1} \\
y_{t \mid t}-y_{t \mid t-1}\end{array}$ & $\begin{array}{c}y_{t}-y_{t \mid t-2} \\
y_{t \mid t-1}-y_{t \mid t-2}\end{array}$ & $\begin{array}{c}y_{t}-y_{t \mid t-3} \\
y_{t \mid t-2}-y_{t \mid t-3}\end{array}$ & $\begin{array}{c}y_{t}-y_{t \mid t-4} \\
y_{t \mid t-3}-y_{t \mid t-4}\end{array}$ & $\begin{array}{c}y_{t}-y_{t \mid t-5} \\
y_{t \mid t-4}-y_{t \mid t-5}\end{array}$ \\
\hline \multicolumn{6}{|c|}{ Panel A: CPI } \\
\hline$\hat{\beta}_{1}$ & $\begin{array}{l}0.99^{* *} \\
(0.05)\end{array}$ & $\begin{array}{l}0.90^{* *} \\
(0.27)\end{array}$ & $\begin{array}{l}0.54^{+} \\
(0.28)\end{array}$ & $\begin{array}{l}0.48^{*} \\
(0.20)\end{array}$ & $\begin{array}{l}1.07^{* *} \\
(0.35)\end{array}$ \\
\hline $\mathrm{N}$ & 30 & 28 & 26 & 24 & 21 \\
\hline$R^{2}$ & 0.852 & 0.351 & 0.114 & 0.119 & 0.209 \\
\hline \multicolumn{6}{|c|}{$\underline{\text { Panel B: GDP }}$} \\
\hline$\hat{\beta}_{1}$ & $\begin{array}{l}1.01^{* *} \\
(0.08)\end{array}$ & $\begin{array}{c}0.58 \\
(0.60)\end{array}$ & $\begin{array}{l}-0.14 \\
(0.61)\end{array}$ & $\begin{array}{c}0.43 \\
(0.72)\end{array}$ & $\begin{array}{l}2.43^{+} \\
(1.19)\end{array}$ \\
\hline $\mathrm{N}$ & 30 & 28 & 26 & 24 & 21 \\
\hline$R^{2}$ & 0.815 & 0.039 & 0.001 & 0.006 & 0.156 \\
\hline \multicolumn{6}{|c|}{ Panel C: Consumption } \\
\hline$\hat{\beta}_{1}$ & $\begin{array}{l}0.86^{* *} \\
(0.14)\end{array}$ & $\begin{array}{c}0.35 \\
(0.37)\end{array}$ & $\begin{array}{c}0.42 \\
(0.31)\end{array}$ & $\begin{array}{c}0.11 \\
(0.23)\end{array}$ & $\begin{array}{c}0.87 \\
(0.62)\end{array}$ \\
\hline $\mathrm{N}$ & 30 & 28 & 26 & 24 & 21 \\
\hline$R^{2}$ & 0.627 & 0.036 & 0.061 & 0.003 & 0.129 \\
\hline \multicolumn{6}{|c|}{ Panel D: Industrial Production } \\
\hline$\hat{\beta}_{1}$ & $\begin{array}{l}0.91^{* *} \\
(0.06)\end{array}$ & $\begin{array}{c}1.31^{*} \\
(0.53)\end{array}$ & $\begin{array}{l}-0.62 \\
(0.38)\end{array}$ & $\begin{array}{c}0.40 \\
(1.17)\end{array}$ & $\begin{array}{c}2.48 \\
(1.72)\end{array}$ \\
\hline $\mathrm{N}$ & 30 & 28 & 26 & 24 & 21 \\
\hline$R^{2}$ & 0.904 & 0.206 & 0.020 & 0.003 & 0.072 \\
\hline
\end{tabular}

Note: Estimated coefficient $\beta_{1}$ from the regression $y_{t}-y_{t \mid t-l-1}=\beta_{0}+\beta_{1}\left(y_{t \mid t-l}-y_{t \mid t-l-1}\right)+\eta_{t} . \quad y_{t \mid t-l}$ are forecasts for variable $y_{t}$ at date $t-l$. Data are from Consensus forecasts at annual frequency. Newey-West standard errors in parentheses. ${ }^{+} \mathrm{p}<0.10,{ }^{*} \mathrm{p}<0.05,{ }^{* *} \mathrm{p}<0.010$.

\section{B Franklin Roosevelt and Shinzo Abe}

Table 7 compares the change in the real interest rate between October 2012 and March 2014 in Japan with that in the U.S. between 1932 and 1934. The first line shows expected inflation before the monetary policy change. For Japan, this is straightforward to measure; one can use either a market measure from inflation swaps or the forecast from Consensus Economics. In the table, we use the value from inflation swaps. Unfortunately, there is no analog to these measures of inflation expectations for the U.S. in $1933 .{ }^{66}$ We consider two possible scenarios. In scenario A, we assume that expected ten-year inflation in 1932 was zero. This is a sensible baseline for two reasons: (1) inflation in the 1920s was near zero. (2) It is a reasonable midpoint given the plausibility of both further deflation and inflation. ${ }^{67}$

In scenarios B and C we apply a simple version of the method used by Cecchetti (1992),

\footnotetext{
${ }^{66}$ Cecchetti (1992) and Hamilton (1992) do provide estimates of expected inflation in the 1930s. But these estimates are for one-quarter ahead inflation and are thus not ideal for our purposes.

${ }^{67}$ Further deflation was plausible given that 1932 was the third consecutive year of large price declines. Many people must have expected these to continue. Inflation was plausible given strong political pressure to raise prices to pre-depression levels (Kennedy, 1999).
} 
Table 7 - Two regime changes

\begin{tabular}{lcccc}
\hline \hline & Japan & U.S., A & U.S., B & U.S., C \\
\hline Expected 10-year inflation pre-policy (\%) & 0.3 & 0.0 & -2.3 & -2.3 \\
Nominal 10-year rate pre-policy (\%) & 0.8 & 3.7 & 3.7 & 3.7 \\
Ex ante 10-year r pre-policy (\%) & 0.4 & 3.7 & 6.0 & 6.0 \\
& & & & \\
& & 1.2 & 1.2 & -0.5 \\
Expected 10-year inflation post-policy (\%) & 1.2 & 3.1 & 3.1 & 3.1 \\
Nominal 10-year rate post-policy (\%) & 0.6 & 1.9 & 1.9 & 3.7 \\
Ex ante 10-year r post-policy (\%) & -0.6 & & -4.1 & -2.4 \\
\hline
\end{tabular}

Hamilton (1992), and Romer (1992) to measure expected inflation. We estimate a three variable VAR with annual data from 1920 to 1940 for real output growth, the change in long-term nominal government bond yields, and CPI inflation. We use one lag. The predicted values for CPI growth are our measure of expected inflation: they represent the best guess of inflation in the future given this model of the economy. Column 3 shows the resulting 1932 forecast of ten-year inflation. With this model of the economy, one would have forecast continued deflation of -2.3 percent per year after 1932 .

Post-policy expected inflation, line 6, is again straightforward to measure for Japan with inflation swaps. In the U.S. case, we consider two possibilities. Scenarios A and B assume that expected inflation equaled actual inflation from 1934 to 1939. In scenario C, we use the ten-year inflation rate predicted by the above-described VAR. Although actual CPI inflation from 1934 to 1939 was just above one percent, the VAR suggests that expected inflation, even in 1934 , was slightly negative (-0.5 percent per year). 


\section{Data appendix}

Activity rates: OECD series LRAC64FE.

CPI: We use the official data from the Japanese Statistics Bureau

(http://www.stat.go.jp/english/data/cpi/).

Employed population age 15-64: OECD series LFEM64TT.

Exchange rate - nominal: We use noon buying rates in New York, as reported by the Federal Reserve (FRED series DEXJPUS). For the announcement table we use the Bloomberg series, USDJPY.

Exchange rate - real: Bank for International Settlements trade-weighted index. We use the broad index including 61 countries.

See http://www.bis.org/statistics/eer/.

Government bond yields: We use the Bloomberg series GJGBX where X is the years to maturity.

Gross and net debt: October, 2013 IMF World Economic Outlook.

Industrial production: Ministry of Economy, Trade, and Industry (4/16/14 release). See http://www.meti.go.jp/english/statistics/tyo/iip/b2010_result-2.html.

Inflation swaps: We use the Bloomberg series JYSWIT2, JYSWIT10.

Land price index in six large Japanese cities: Statistics Bureau's Urban Land Price Index. The six cities are Tokyo, Yokohama, Nagoya, Kyoto, Osaka, and Kobe.

Money market interest rate: IMF, International Financial Statistics.

Money supply: Both the monetary base and the broad money supply are from the Bank of Japan. We follow the Bank of Japan's recommendation and compare the old series for M3 + CDs - money trusts with the new series for M3.

See http://www.boj.or.jp/en/statistics/outline/exp/data/exms01.pdf.

Multifactor productivity: OECD StatExtracts, multifactor productivity table.

Nominal hourly earnings: We compute hourly earnings as the ratio of total monthly wages to hours worked. Data are from the final report of the Monthly Labor Survey from the Ministry of Health, Labor and Welfare

(http://www.mhlw.go.jp/english/database/db-l/25/2512re/2512re.html).

Real GDP and GDP deflator: Official Japanese real GDP are available from the Japanese Cabinet office (http://www.esri.cao.go.jp/en/sna/menu.html). These data begin in 1994. Prior to 1994, we use the real GDP index from the IMF's International Financial Statistics. We ratio splice this series to the official series in 1994.

Real GDP - PPP-adjusted: The OECD's measure of constant-PPP, constant-prices GDP.

Share of electricity from nuclear power: See

http://www.eia.gov/countries/cab.cfm?fips=ja.

Stock market: We use Nikkei 225 data from Yahoo finance and Topix data from the Bloomberg series TPX.

Trade shares and quantities: Trade shares are from the Ministry of Finance, Trade Statistics of Japan. This is also the source for data on changes in trade quantities and values. See http://www.customs.go.jp/toukei/shinbun/happyou_e.htm.

Unemployment rate: We use the OECD series LRUNTTTT.

Working age population: We use the OECD series for the population age 15 to 64 , LFWA64TT.

U.S. data in table 1: Real GDP: Federal Reserve Bank of St. Louis, FRED database 
series GDPCA. Other series as above.

U.S. 1930s comparison (including table 7): CPI: Federal Reserve Bank of St. Louis, FRED series CPIAUCNS. Real output growth: prior to 1929, this is measured as the percent change in the real GNP series constructed by Romer (1989). In 1929, this series is spliced to the Bureau of Economic Analysis' series for real GDP measured in chained 1937 dollars (NIPA table 1.1.6A). Industrial production: Federal Reserve Bank of St. Louis, FRED series INDPRO. Long-term government bond yields: From 1919 to 1925, this is the average yield on U.S. government bonds due or callable after eight years. After 1925, it is the average yield on U.S. government bonds due or callable after 12 years. The series is presented and described in the August 1938 Federal Reserve Bulletin, p. 1045. We take the data from the NBER macrohistory database series m13033. 